\title{
CORPORATE TAX EFFECTS ON THE QUALITY AND QUANTITY OF FDI
}

\author{
Johannes Becker \\ Clemens Fuest \\ Nadine Riedel
}

OXFORD UNIVERSITY CENTRE FOR BUSINESS TAXATION SAÏD BUSINESS SCHOOL, PARK END STREET OXFORD OX1 1HP 


\title{
Corporate tax effects on the quality and quantity of FDI *
}

\author{
Johannes Becker*, Clemens Fuest ${ }^{\ddagger}$ and Nadine Riedel ${ }^{\S}$
}

This version: 1st June 2010

\begin{abstract}
This paper measures the relative importance of quality and quantity effects of corporate taxation on foreign direct investment. Quantity is affected if corporate taxes reduce the equilibrium stock of foreign capital in a given country. Quality effects arise if taxes decrease the extent to which investment contributes to the corporate tax base and the capital intensity of production. Depending on the sign of the quality effects, the detrimental welfare effects of corporate taxation are either mitigated or aggravated. We derive a number of hypotheses how corporate tax changes may affect the quality of investment. Our hypotheses are then tested using data from a large sample of European multinationals. With regard to corporate tax effects on the corporate tax base, we find that quality effects account for up to fourty per cent of the total effect. With regard to corporate tax effects on labour income, our results suggest that quality effects mitigate the negative quantity effect by nearly sixty percent (as corporate taxes strongly increase the labor intensity of production). An important implication is that governments should not exclusively care about the size of inbound FDI flows but also about their specific characteristics, i.e. their quality.
\end{abstract}

JEL Codes: H25, F23

Keywords: Corporate Taxation, Foreign Direct Investment, Multinational Firms

*We thank Nadja Dwenger, Andreas Haufler, Martin Hellwig, Harry Huizinga, Christian Keuschnigg, Kai Konrad, Viktor Steiner and participants at research workshops in Berlin, Bonn, Florence, Munich and Tilburg for helpful comments on an earlier version of the paper. We gratefully acknowledge financial support from the ESRC (Grant No RES -060-25-0033).

* Max Planck Institute for Intellectual Property, Competition and Tax Law, Marstallplatz 1, 80539 Munich, Germany. E-Mail: johannes.becker@ip.mpg.de

$\ddagger$ Centre for Business Taxation, Saïd Business School, University of Oxford, Park End Street, Oxford OX1 HP, UK. E-Mail: clemens.fuest@sbs.ox.ac.uk

${ }^{\S}$ Centre for Business Taxation, Saïd Business School, University of Oxford, Park End Street, Oxford OX1 HP, UK. E-Mail: nadine.riedel@sbs.ox.ac.uk 


\section{Introduction}

The last decades experienced an unprecedented boom in foreign direct investment (FDI). In 2008, the worldwide stock of inward FDI was USD 14,909 billion, only slightly less than its alltime high in 2007, compared to only USD 1, 457 billion in 1988 (source: UNCTAD). ${ }^{1}$ While multinational firms are seen to be the main driving force behind FDI growth (see, e.g., Bernard \& Jensen, 2007, Bernard et al., 2007), governments throughout the world have supported this trend by improving the policy environment for border crossing investment. From a policy perspective, attracting FDI is widely considered to be beneficial for the host country because this investment is thought to provide new growth opportunities, higher wages, larger tax revenues - in short: a higher welfare level.

Among the policy instruments which can be used to attract investment, taxes play a key role. In the last decades, many countries have reduced their corporate tax rates in order to attract FDI (see, e.g., Devereux, Griffith \& Klemm, 2002, Loretz 2008). ${ }^{2}$ Empirical research has measured the effects of these tax reforms and finds that there is indeed a strong and robust impact of corporate tax cuts on the quantity of inbound FDI. ${ }^{3}$ However, as an indicator of success, the quantity of assets attracted by a corporate tax rate cut may be misleading or at least incomplete. The reason is that the welfare of the host country will depend on the impact of FDI on tax revenue and labour income generated by the investment and much less on the mere investment quantity. In this paper, we argue that taxes do not only affect the quantity of (inbound) FDI but also its quality, i.e. the degree to which FDI creates jobs and how it contributes to tax revenue in the host country. We will show empirically that taking into account the quality aspect of FDI has considerable consequences for optimal tax policy.

\footnotetext{
${ }^{1}$ See the UNCTAD Handbook of Statistics 2009, available on www.unctad.org. For purpose of comparison, the subgroup of developed countries had a stock of inward FDI of USD 1,000 billion in 1988 and of USD 10,212 billion in 2008. All numbers are in current prices and exchange rates.

${ }^{2}$ Effective average tax rates, which are likely to be the relevant indicator for firm location have been reduced from 37.4 per cent in 1982 to 23.9 per cent in 2007, see Loretz (2008).

${ }^{3}$ These studies are surveyed and discussed in de Mooij and Ederveen (2003) and Devereux (2007).
} 
For purpose of illustration, consider the following example. A multinational firm sets up two new affiliates, one in Ireland, the other in Spain. The two investment projects are equal in terms of quantity, i.e. the amounts of capital invested in each country are identical. However, due to the low Irish corporate tax rate, the highly profitable financing department is located in Ireland while the industrial assembly lines, with low profitability and a large payroll, which is deductible from the corporate tax base, are located in Spain. How are these investments to be evaluated in welfare terms? According to the conventional quantity-based success indicator, both countries were equally successful in attracting FDI. However, the investment in Ireland boosts the Irish corporate tax base while the investment located in Spain only marginally adds to the Spanish corporate tax base. It increases labour income in Spain, though, and boosts Spanish payroll tax revenue. Thus, the Spanish and the Irish investment are equal in quantity but very different in quality. Both investment characteristics, quantity and quality, are potentially affected by the level of corporate tax rates (Ireland attracts the profitable investment, Spain the labour-intensive one). Measuring the quantity and quality effects of corporate taxes on FDI is in the focus of this paper.

In the first part of the paper, we propose a simple model in order to explain and define precisely our notion of quantity versus quality. We consider a model of a small open economy where a benevolent government sets the corporate tax rate so as to maximize national welfare. Corporate tax policy faces a trade-off between the objectives of raising more revenue from a given tax base and attracting additional investment. We show that the optimal tax rate is a function of the quantitative and qualitative tax rate elasticities of investment. In order to operationalize the model for empirical analysis, we derive three hypotheses concerning the effects of corporate tax rate increases on the quality and quantity of FDI. Hypothesis 1 states, not surprisingly, that a higher corporate tax rate decreases the quantity of investment. Hypothesis 2 says that a higher corporate tax rate reduces the contribution of each unit of capital to the corporate tax base. Hypothesis 3 claims that a higher corporate tax rate increases the 
labour income generated per unit of investment. While the first hypothesis is theoretically straightforward and empirically well established, the second and third hypotheses require some further discussion.

To begin with hypothesis 2 , the reason for a negative quality effect may be transfer pricing or thin capitalization, as has been extensively shown by the literature. ${ }^{4}$ These studies interpret profitability differences between high- and low-tax economies as evidence for paper shifting behaviour and usually find that tax differences across locations of a multinational group are a strong predictor for the location of accounting profits. It may also be that this pattern is caused by the mobility of firms with different levels of profitability (Haufler \& Stahler, 2009) or project selection within multinational firms (Becker \& Fuest, 2009). Note, though, that taxation may theoretically also increase the average profitability of investment. This is the case if taxes mainly drive out the least profitable investment projects, so that the average profitability of investment projects remaining in the country increases.

Consider finally hypothesis 3 , which states that a higher corporate tax rate increases the amount of labour income generated per unit of investment. A reason for this could be that the production technology allows for the substitution of capital by labour. Alternatively, capital intensive tasks may be relocated to a foreign location within the multinational group. ${ }^{5}$ This effect is economically important because an important benefit that governments associate with inbound FDI is increased wages and/or reduced unemployment. If the third hypothesis is supported by the data, the negative welfare effect of a tax-induced reduction of investment is partly mitigated by the higher labour intensity of production. However, it cannot be excluded that the decrease in the capital intensity of production reduces wages. In this case, the efficiency cost of corporate taxation may even be aggravated by the quality effect.

Taken together, a change in the host country's corporate tax rate may affect the quantity of inbound investment as well as the quality of each incoming unit of invest-

\footnotetext{
${ }^{4}$ See e.g. Grubert \& Mutti (1991), Hines \& Rice (1994), Huizinga \& Laeven (2008), Dischinger (2008), Dischinger \& Riedel (2008) and Weichenrieder (forthcoming).

${ }^{5}$ See Becker \& Fuest (2007) and, in a tax-unrelated context, Grossman \& Rossi-Hansberg (2008).
} 
ment. The size and the sign of these effects on quantity and quality will determine the optimal tax rate. We argue that, depending on the sign and the size of the quality effects of corporate taxation, neglecting these quality effects implies that the efficiency cost of taxation is either underestimated or overestimated.

In the second part of the paper, we test these hypotheses using micro-level firm data from a large panel of European corporations. We find evidence for the quantity effect and both quality effects. Firstly, increases in the corporate tax rate decrease the quantity of foreign capital invested. Secondly, corporate taxes tend to reduce the contribution to the corporate tax base per capital unit. With respect to the corporate tax base, our results suggest that the quality effect reinforces the quantity effect and accounts for around 40 per cent of the overall effect. Thirdly, increasing corporate tax rates ceteris paribus increases the labour income generated per unit of corporate investment. This compensates the negative quantity impact of corporate taxes on payroll by around 60 per cent.

So far, the literature has mainly treated quantity and quality effects of taxation separately (see the literature cited above). Recently, however, there is increased attention to welfare implications of corporate taxes. Gruber \& Rauh (2007) and Dwenger \& Steiner (2008) measure the tax base elasticity with regard to corporate tax rate changes. This elasticity can be interpreted as a summary measure of corporate tax effects. Due to data limitations, though, quantity effects cannot be differentiated from quality effects. Arulampalam et al. (2007) deal with the incidence of corporate taxes on wages. They find that an increase in corporate taxes is associated with a significant wage decrease. Here, quantity effects of taxes are only accounted for as far as they affect the wage rate. To the best of our knowledge, our paper is the first to explictly analyze quantity and quality effects of corporate taxation from a welfare perspective.

From a policy perspective, the distinction between quality and quantity effects of corporate tax rate changes is of key importance. For example, it may well be that countries with high taxes attract primarily low profitability investment or even investment 
which generates tax losses. The quantity of investment may not differ much from that of other countries, but the welfare effects of this investment would be different because the investment diminishes the tax base. Thus, the welfare cost of tax distortions may be higher than suggested by studies focusing on the quantity aspect alone. In contrast, if FDI is mainly supposed to increase employment and/or wages, our findings suggest that a tax-induced reduction in FDI is mitigated by a simultaneous increase in labour intensity. In general, policies which aim at attracting foreign direct investment may have to pay more attention to the qualitative dimension of this investment.

The rest of the paper is set up as follows. In section 2, we derive the hypotheses which are used in the empirical section 3. Section 4 concludes.

\section{A simple model of optimal corporate tax policy with quality and quantity effects}

In the following, we develop a highly stylised model of corporate taxation in an open economy in order to explain the difference between tax effects on the quality and quantity of investment.

Consider an open economy with many identical households and two production sectors. Domestic welfare is given by $W=Y+\eta G$, where $Y$ is disposable income of domestic residents, $\eta$ is the marginal utility of public expenditure (or the marginal cost of public funds) and $G$ is aggregate public expenditure.

There are two production sectors. The first sector is an international industrial sector employing internationally mobile capital and internationally immobile labour. The second one is a domestic service sector where labour is the only input. To make things very simple, we assume that overall payroll is given by $P+s(N-P)$, where $P$ is payroll in the industrial sector and $s(N-P)$ is payroll in the domestic service sector. This stylized formulation implies that a decline in payroll generated in the industrial sector by one unit will be replaced by $s$ units of payroll in the domestic service sector. 
For instance, assume that the technology in the service sector is linear, so that the wage rate is pinned down in this sector. If there is perfect wage flexibility in the international sector and labour is perfectly mobile across sectors, wages in both sectors would be equated and we would have $s=1$. In this case, the fact that investment in the industrial sector creates more jobs in this sector would have no impact on domestic welfare because labour would only be reallocated from the service sector and neither disposable labour income nor (labour) tax revenue would change. But if $s<1$, more employment in the international sector would also increase labour income in the economy as a whole. ${ }^{6}$

Disposable income of domestic residents, $Y$, consists of after-tax labour income and a share $\phi \in[0,1]$ of after-tax corporate profits generated in the industrial sector. Profits in the service sector are equal to zero. The parameter $\phi$ is the domestic ownership share in industrial sector firms. Domestic ownership of firms located abroad is ruled out for simplicity. Thus, disposable income is given by $Y=(P+s(N-P))\left(1-t^{P}\right)+\phi B\left(1-t^{B}\right)$, where $P$ is payroll in the industrial sector, $B$ stands for corporate profits generated in the domestic economy, $t^{P}$ and $t^{B}$ are proportional taxes on labour income and corporate profits, respectively. Accordingly, government expenditure is given by $G=$ $t^{P}(P+s(N-P))+t^{B} B$. FDI affects domestic welfare by changing payroll, profits and tax revenue.

For later use, denote the quantity of FDI in the country by $k$ and define payroll per unit of capital, $p \equiv P / k$, and corporate profits per unit of capital, $b \equiv B / k$. The country's welfare function can now be expressed as

$$
W=\alpha s N+(\alpha(1-s) p+\beta b) k
$$

where $\alpha \equiv 1+(\eta-1) t^{P}$ and $\beta \equiv \phi+(\eta-\phi) t^{c}$ are the social marginal utility of labour income and profits, respectively. In this welfare function, the variables $p$ and $b$

\footnotetext{
${ }^{6}$ It would be straightforward to write down an explicit model with a dual labour market with these properties. However, this would divert attention from the focus of this paper without adding many new insights.
} 
reflect the qualitative dimension of domestic investment; $p$ is the average labour income "generated" per unit of FDI and $b$ is the value of the corporate tax base per unit of investment. The quantitative dimension is captured by the investment level $k$. The impact of a change in the corporate tax on welfare can now be expressed as

$$
\frac{\partial W}{\partial t^{c}}=(\eta-\phi) b k+(\alpha(1-s) p+\beta b) \frac{\partial k}{\partial t^{c}}+\alpha(1-s) k \frac{\partial p}{\partial t^{c}}+\beta k \frac{\partial b}{\partial t^{c}}
$$

The effect of the tax change on the quantity of investment is captured by the second term on the right hand side of (2) while the effects on the quality of investment is given by the third and the fourth term. By setting the right hand side of (2) equal to zero we can derive a formula for the optimal corporate tax rate:

$$
t^{c *}=-\frac{1}{\varepsilon_{k}+\varepsilon_{b}}-\frac{\alpha(1-s)}{(\eta-\phi)} \frac{p}{b} \frac{\left(\varepsilon_{k}+\varepsilon_{p}\right)}{\left(\varepsilon_{k}+\varepsilon_{b}\right)}-\frac{\phi}{(\eta-\phi)}
$$

where $\varepsilon_{k} \equiv \frac{\partial k}{\partial t^{c}} \frac{1}{k}, \varepsilon_{p}=\frac{\partial p}{\partial t^{c}} \frac{1}{p}$ and $\varepsilon_{b}=\frac{\partial b}{\partial t^{c}} \frac{1}{b}$ are semi-elasticities representing the quantity and quality effects of corporate taxation. We will return to this formula further below. What should we expect regarding the sign of the quantity and quality effects? It would be straightforward to write down a model of a firm employing labour and capital to derive the effects. Since this is very standard in the literature, we restrict ourselves to a discussion of what such a standard model would generate. The sign of the quantity effect will usually be negative, i.e. $\varepsilon_{k}<0 .{ }^{7}$ For the quality effects $\varepsilon_{b}$ and $\varepsilon_{p}$, predictions are less clear.

Consider first the impact of tax changes on the amount of payroll per unit of investment. For a given non-tax cost of capital, an increase in the corporate income tax increases the cost of capital relative to the cost of labour. If the firm is able to substitute capital with labour input, this increases the payroll (due to higher labour input or higher wages) for a given level of investment. However, if capital and labour are technological complements, a decrease in the stock of capital reduces labour productivity

\footnotetext{
${ }^{7}$ Theoretically, a higher tax rate could also reduce the cost of capital, in particular in the presence of accelerated depreciation.
} 
which, for a given level of investment, reduces payroll (due to lower wages). It is a priori unclear which of the two effects prevails, i.e. whether the quality of investment in terms of generating labour income increases or decreases in response to a change in the corporate tax rate.

Now, consider the effect of a corporate tax rate change on the the corporate tax base per unit of investment. Higher corporate tax rates are likely to increase both the marginal and the average tax burden. If only the marginal and, thus, least profitable projects are driven out of the market, the corporate tax base per capital unit may actually increase. If, however, economic rents are not bound to the country under consideration, firms might move profitable operations to other countries. The incentives to move real economic activity to other countries created by the higher tax are the stronger, the higher the profitability of the activity. This suggests that firms will move the most profitable functions first, so that the corporate tax base per capital unit may actually decrease. Moreover, firms are likely to react to the higher corporate tax by shifting book profits abroad through transfer pricing, debt financing and so on. Again, it is unclear which of the two effects is stronger, i.e. whether the quality of investment in terms of generating corporate tax revenue increases or declines.

These considerations can be summarized as

Hypothesis 1 (Quantity) An increase in $t^{c}$ decreases the capital stock $k: \varepsilon_{k}<0$.

Hypothesis 2 (Quality - Tax Base Contribution) An increase in $t^{c}$ decreases the contribution to the corporate tax base per unit of investment $b$ : $\varepsilon_{b}<0$.

Hypothesis 3 (Quality-Labour Income Contribution) An increase in $t^{c}$ increases the payroll-capital ratio $\varepsilon_{p}>0$.

Note that, from a theoretical perspective, hypotheses 2 and 3 may be stated with opposite signs. As explained above, the signs and the magnitudes of the quality and quantity effects are important for corporate tax policy. In the next section, we use firm data to directly estimate the quantity and quality effects $\varepsilon_{k}, \varepsilon_{b}$ and $\varepsilon_{p}$. 


\section{Data}

We use the commercial database AMADEUS compiled by Bureau van Dijk. The version of the database available to us contains detailed information on firm structure and accounting of national and multinational corporations in European countries. Our sample contains information on multinational affiliates in 22 countries (Austria, Belgium, Czech Republic, Denmark, Finland, France, Germany, Great Britain, Greece, Hungary, Iceland, Ireland, Italy, Luxembourg, Netherlands, Norway, Poland, Portugal, Slovakia, Spain, Sweden, Switzerland) for the time period 2000 to $2006 .{ }^{8}$ Precisely, firms are included into the analysis if either their parent company or one of their wholly owned subsidiaries is located in a foreign economy. A country distribution of our sample affiliates is presented in Table $1 .^{9}$

The observational unit in our analysis is the multinational affiliate per year. In total, our sample comprises 101, 059 observations from 26, 473 affiliates for the years 2000 to 2006. Hence, we observe each affiliate for 3.8 years on average. Besides the rich set of accounting information available in AMADEUS, we enlarge our data set by merging information on the country's tax system, i.e. statutory corporate tax rates, effective marginal tax rates and the present values of capital allowances, obtained from European Commission (2006), KPMG (2006) and Loretz (2008). Moreover, we add information on GDP as a proxy for market size, GDP per capita as a proxy for a country's income and development level, the unemployment rate as a proxy for the state of a country's economy and the corruption index as a proxy for the state of governance institutions. The corruption index is obtained from Transparency International while the other country data is retrieved from the World Development Indicator Database. Last, we add information on the labour tax wedge obtained from OECD's tax data

\footnotetext{
${ }^{8}$ The AMADEUS data is in principle available since 1999. However, as we observe some of our tax information for 2000 onwards only, we restrict the sample to the years 2000 to 2006 .

${ }^{9}$ Note that the country statistic broadly corresponds to the distribution of economic activity in Europe. Nevertheless, in line with previous work, we also find that some countries are underrepresented in the AMADEUS data, for example Germany and Switzerland, which suggests that some caution is warranted when drawing conclusions from our results for the population of firms in these countries.
} 
base which is measured as the marginal tax burden of a worker who earns the country's median income (whereas the results are however robust against evaluating the labour tax wedge at other points of the income distribution).

- Table 1 here -

Note that not only the host country's corporate tax rate but also the tax rate differential to other firms within the same multinational group may have an impact on affiliate behavior. For instance, profit shifting or the choice of locations for projects may depend on these tax rate differentials, rather than tax rates of individual countries. We use our data set to construct a tax measure which captures these effects. As the AMADEUS data contains information on the ownership structure of multinational groups on a worldwide basis (while the accounting information is restricted to firms located in Europe), we observe all group affiliates worldwide and their host countries. To construct the tax difference measure, we identify a firm's global ultimate owner and consider all its majority owned subsidiaries to be affiliates within the multinational group. Then, we calculate an unweighted average tax rate differential between the considered affiliates and all other majority owned firms in the multinational group (including the parent if the considered firm is not an independent company itself). ${ }^{10}$

Table 2 displays basic sample statistics. The affiliates in our sample observe an average fixed asset investment of USD 166.0 million, employ 543.7 employees and have average yearly costs per worker of USD 62.5 thousand. Labour intensity, defined as labour-to-fixed asset-ratio and payroll-to-fixed asset-ratio, is determined with 0.14 and 8.14 respectively. Corporate pre-tax profitability (measured as pre-tax profits over total assets) is 12.64 per cent. Pre-tax profitability is used to proxy the firm's corporate tax base. Although accounting profits may diverge from the the firm's tax book profit

\footnotetext{
${ }^{10}$ An alternative procedure would be to calculate a size weighted average tax differential. However, as the size information is unavailable for a large number of group affiliates in our data (especially those located outside Europe), this would imply that we lose a considerable number of observations in the calculation of the tax rate difference variable. Thus, we decided to employ the unweighted measure in our baseline estimations. In robustness checks, we however reestimated the regression models using size weighted averages and did not find our qualitative results to change.
} 
(e.g. Hanlon and Maydew, 2009), they are nevertheless widely considered to be a good proxy for the the corporate tax base, especially for European countries in which the divergence between accounting and tax books is less pronounced than for example in the US (see e.g. Huizinga and Laeven, 2008).

Moreover, the firms in our data base on average face a corporate tax rate of 32.5 per cent which varies strongly between 10 and 51.6 per cent. The unweighted average tax rate differential between the affiliate and other firms within the multinational group is determined with 0.6 per cent but equally exhibits a strong spread between -31.1 and +35.6 per cent. The effective marginal tax rate is calculated with 11.31 per cent varying between 0.1 and 17.27 per cent while the average present value of capital allowances is 66.0 per cent ranging from 53.4 to 74.6 per cent. Last, the marginal labour tax wedge for employees with the mean country income is 52.1 per cent, varying between 33 per cent and 77 per cent.

Additionally, our sample firms' host countries exhibit an average GDP of USD 990.3 billion, an average GDP per capita rate of USD 30,250.8, an average unemployment rate of 7.5 per cent and an average corruption index of 7.5 (on a scale from 0 (poor) to 10 (excellent) indicating the quality of governance institutions).

- Table 2 here -

\section{Estimation Approach}

In order to disentangle quality and quantity effects of corporate taxation, we determine the impact of corporate tax rate changes on the size of a firm's capital stock (quantity effect) and on the profitability and payroll intensity of investment (quality effects). Let $k, b$ and $p$ denote the investment quantity, profitability and payroll intensity. Quality and quantity effects are estimated in a static and dynamic investment framework where 
the static model reads

$$
\log x_{i, t}=\beta_{0}^{x}+\beta_{1}^{x} \tau_{i, t}^{x}+\beta_{2}^{x} Z_{i, t}^{x}+\rho_{t}^{x}+\phi_{i}^{x}+\epsilon_{i, t}^{x} \quad \text { with } x \in\{k, b, p\}
$$

with $x_{i, t}$ representing the fixed asset stock, profitability or payroll intensity of affiliate $i$ at time $t$. As the distributions of all three variables are strongly skewed, we use logarithmic transformations as regressands. ${ }^{11} \tau_{i, t}^{x}$ depicts a measure for the corporate tax burden of affiliate $i$ at time $t$. The superscipt $x \in\{k, b, p\}$ indicates the variable definition in the regressions using fixed assets, profitability and the payroll intensity as the dependent variable. In the baseline specifications, the variable takes the form of the statutory tax rate $t_{i, t}$. The profitability and payroll intensity regressions moreover account for a second tax measure which is the unweighted tax rate differential between the affiliate and other firms in the multinational group as defined in the previous section. Including the tax rate differential takes into accout that, conditional on the affiliate location, the multinational's decision where to locate its profitable and/or labor intensive investment projects may depend on the tax structure of the overall group.

$Z_{i, t}^{x}$ comprises time varying firm-specific and country-specific control characteristics. Country-specific control variables are used to absorb variations in market size (proxied by GDP), income level (proxied by GDP per capita), state of the economy (proxied by the unemployment rate) and quality of governance institutions (proxied by the corruption index). Firm-specific control variables are used depending on the regressand $x$. In the regressions which employ the affiliates' profitability and payroll intensity as the dependent variable, we include a control variable for affiliate size as measured by sales (the results being robust against using other size controls like the number of employees or total assets). The profitability regressions moreover include a control variable for the affiliate's labour intensity. $\rho_{t}^{x}$ depicts year dummies to capture shocks over time which are common to all affiliates, in some specifications we additionally

\footnotetext{
${ }^{11}$ As this is also true for the distribution of profitability (see, e.g., Huizinga and Laeven, 2008), the sample is restricted to affiliates with positive pre-tax profits which we consider to be sensible in our context as tax considerations plausibly only play a role for firms with a positive tax base.
} 
include a full set of industry-year dummies (at the two-digit level) to account for industry-specific shocks over time. $\epsilon_{i, t}^{x}$ describes the error term. Moreover, we add fixed effects for multinational affiliates to control for non-observable time-constant firm specific characteristics $\phi_{i}^{x}$.

A shortcoming of the static estimation approach described in equation (4) is that it does not take into account the costs associated with adjusting capital or labour demand at the firm level and consequently neglects that the subsidiary's capital and labour stock is dependent on the stocks of previous periods. Therefore, we additionally estimate a dynamic model. Since including the first lag of the dependent variable into the set of regressors in a fixed effects framework leads to biased coefficient estimates, we follow Arellano and Bond (1991) in estimating a first difference generalized method of moments (GMM) model which instruments for the first difference in the lagged dependent variable by deeper lags of the level of the dependent variable. ${ }^{12}$ The estimation equation then takes on the following form

$$
\Delta \log \left(x_{i, t}\right)=\gamma_{1}^{x} \Delta \log \left(x_{i, t-1}\right)+\gamma_{2}^{x} \Delta \tau_{i, t}^{x}+\gamma_{3}^{x} \Delta Z_{i, t}^{x}+\Delta \rho_{t}^{x}+\Delta \epsilon_{i, t}^{x} \quad \text { with } x \in\{k, b, p\}
$$

where $\Delta$ depicts the difference operator and the variable definitions correspond to the ones in equation (4). ${ }^{13}$ Because the model is estimated in first differences, the equation will be characterized by the presence of first order serial correlation. However, the validity of the GMM estimator relies on the absence of second order serial correlation. The Arellano and Bond (1991) test statistic for second order serial correlation will be reported at the bottom of the result tables. We check for the exogeneity of the

\footnotetext{
${ }^{12}$ Note that the difference in the lagged dependent variable correlates with the differenced error term. However, deeper lags (starting from the second lag) of the dependent variable (in levels) are available as valid instruments as they are orthogonal to the error term.

${ }^{13}$ With panel data on more than two time periods, it is not equivalent to apply a fixed effect and first differencing approach respectively. Both models give unbiased and consistent estimates although the relative efficiency of the estimators may differ, depending on the model structure. Precisely, the fixed effect estimator is less sensitive against the violation of strict exogeneity of the regressors while the first differencing estimator is less sensitive against the violation of serially uncorrelated error terms. Our results, however, turn out to be largely robust against using fixed effects and first differencing estimators.
} 
instrument set by employing a Sargan/Hansen overidentification test. ${ }^{14}$

In the profitability regressions, we find - in line with previous studies - only a shallow serial correlation in the pre-tax profit variable and thus refrain from presenting dynamic specifications in the paper $\left(\gamma_{1}^{b}=0\right)$. However, the profitability estimations may be especially prone to reverse causality problems. It may well be the case, that it is not only size and labour intensity which affect the reported pre-tax profit per capital unit but that in reverse corporate profitability also drives the firm's investment and employment decision. Therefore, we employ the levels estimator proposed by Anderson and Hsiao (1982) which suggests to control for time constant affiliate effects by taking the first differences of the estimation equation and to instrument for the difference in the endogenous variable by employing lagged levels of this variable. Our result tables will report the Kleibergen/Paap test statistic for the relevance of the instruments at the first stage and the Sargan/Hansen test of overidentifying restrictions to assess the validity of the instruments employed..$^{15}$

\section{Results}

The regression results are depicted in Tables 3 to 7 . All specifications include a full set of year fixed effects. Heteroskedasticity robust standard errors which account for clustering at the firm level are calculated and presented in brackets below the coefficient estimates.

In Table 3, we identify the quantity effect of corporate taxation and thus measure the impact of corporate rate changes on the firm's capital stock. Specifications (1) to (4) present the results for the static fixed-effects model which is described by equation (4) in the previous section. In column (1), a baseline estimation is presented without any additional control variables. Columns (2) and (3) show the results of

\footnotetext{
${ }^{14}$ We will present results for the standard dynamic specification including only the first lag of the dependent variable. However, in robustness checks we accounted for deeper lags of the dependent variable and did not find our results to be affected.

${ }^{15}$ In robustness checks, we also reran the specification using the GMM estimator proposed by Arellano and Bond (1991) described above and found comparable results.
} 
regressions including a set of time-varying country-specific control variables (precisely the host country's GDP, GDP per capita, the corruption index, unemployment rate, the present value of capital allowances) and a full set of industry-year fixed effects. In all three specifications, the estimations show a strongly and significantly negative semielasticity of investment with respect to changes in the corporate tax rate. According to specification (3), a one percentage point increase in the corporate tax rate decreases the capital stock by 1.4 per cent. Specification (4) reestimates the regression in column (3) merging the information on the statutory corporate tax rate and depreciation allowances into one measure, the effective marginal tax rate on an investment project. This regression confirms the significantly negative impact of the effective marginal tax rate on capital investment.

In specifications (5) to (8) we reestimate the causal effect of corporate taxation on a firm's capital investment in a dynamic framework as specified in equation (5). All four specifications indicate that capital investment is sticky as the coefficient estimate for the lagged dependent variable is positive and quantitatively large. Most importantly, the estimations confirm the negative effect of corporate taxes on subsidiary investment whereas the coefficient estimate for the corporate tax effect remains sizable. Column (7) suggests that a one percentage point increase in the corporate tax rate at the subsidiary's host location reduces capital investment by 1.1 per cent in the short run. The long run effect is larger and estimated with 1.8 per cent (and is thus quantitatively in line with previous results in the literature, see e.g. de Mooij and Ederveen, 2005). ${ }^{16}$

- Table 3 here -

The validity of the Arellano and Bond (1991) approach relies on two assumptions: the exogeneity of the instrument set with respect to the error term and the absence

\footnotetext{
16 The long-run effect is estimated by multiplying the coefficient estimate for the corporate tax rate with $1 /\left(1-\gamma_{1}\right)$ with $\gamma_{1}$ being the coefficient estimate for the lagged dependent variable in the dynamic panel model. Note that the sample size for the dynamic estimations is smaller than for the fixed effects specifications since for firms to be included in the dynamic estimation framework, we have to observe the fixed asset variable for at least three successive periods (to construct the first difference of the dependent variable and the first difference of the lagged dependent variable). This implies that firms with less successive observations are dropped from the estimation.
} 
of second order autocorrelation. As indicated in the previous chapter, we apply a Sargan/Hansen overidentification test to check the former assumption and the Arellano and Bond (1991) test for second order autocorrelation to check the latter one. The test statistics are reported at the bottom of Table 3 and indicate that the estimation strategy is valid.

In Tables $4 \mathrm{a}$ and $4 \mathrm{~b}$, we present the first part of our quality estimations with regard to the pre-tax profitability of corporate investment. Specifications (1) to (4) of Table 4a follow a standard fixed effects approach. While column (1) contains the baseline estimation, columns (2) and (3) add time-varying control variables and a full set of industry-year dummies. Column (4) additionally controls for the affiliate's labour intensity and affiliate sales as a proxy for firm size. The corporate tax rate is found to exert a strong and significantly negative impact on corporate profitability in all specifications. Quantitatively, column (4) suggests that an increase in the corporate tax rate by one percentage point reduces the pre-tax profit per asset unit by 1.3 per cent.

In column (5) we reestimate specification (4) but additionally account for potential reverse causality with respect to labour intensity and firm size applying the instrumental variables approach proposed by Anderson and Hsiao (1982). For the specifications to be valid, the chosen instrument set of lagged levels of the input factors has to be a relevant predictor of the first-differenced inputs and it has to be uncorrelated with the error term. Both assumptions are confirmed by the test statistics for the Sargan/Hansen test and the Kleibergen-Paap test presented in the table. Interestingly, accounting for reverse causality confirms the positive impact of the labour intensity on the firm's pre-tax profitability reported in the OLS fixed effects specifications while the size effect on pre-tax profitability turns negative, indicating that the corporate pre-tax profitability tends to fall with firm size. Moreover, the estimated corporate tax effect on affiliate profitability is quantitatively unchanged. This result is robust against normalising pre-tax profits on other input factors like sales or the number of 
employees. Specifications (6) and (7) reestimate the regressions in columns (4) and (5) but employ pre-tax profits over fixed assets as the dependent variable which yields comparable results. ${ }^{17}$

So far, our estimations have only determined the effect of corporate tax rate changes on affiliate investment. However, the corporate tax difference between the affiliate and other firms within the same multinational group may also be an important predictor of firm profitability. Accordingly, we reestimate the specifications presented in Table 4a employing the corporate tax rate difference between the affiliate and other group members as a tax determinant. The results are presented in Table $4 \mathrm{~b}$ and indicate that the profitability per capital unit is significantly larger the smaller the affiliate's corporate tax rate relative to other group members' tax rates. Specification (5) suggests that an increase in the tax rate differential by one percentage point reduces the subsidiary's asset profitability by 1.1 per cent.

- Tables 4a and 4b here-

The second part of our quality estimations focuses on labour intensity and is presented in Tables $5 \mathrm{a}$ to $6 \mathrm{~b}$. Tables $5 \mathrm{a}$ and $5 \mathrm{~b}$ depict the results for regressions employing the labour-to-fixed asset-ratio as dependent variable. Column (1) presents the baseline specifications including the corporate tax rate and a full set of affiliate and year fixed effects which is augmented by the time-varying country controls GDP, GDP per capita, the corruption index and the unemployment rate in Column (2) and by industry-year fixed effects in Column (3). In columns (4) and (5), we additionally account for the impact of the labour tax wedge, capital allowances, affiliate size (as measured by sales), the average worker's wage rate and firm profitability (as measured by pre-tax profits over fixed assets). The corporate tax rate exerts a statistically significant and positive effect on the labour-to-fixed asset-ratio in all specifications. Quantitatively, column

\footnotetext{
${ }^{17}$ Note that the sample size drops in the instrumental variable estimations compared to the fixed effects specifications as for firms to be included in the instrumental variables regressions two successive observations for the regressand (and the regressors) have to be available in the data plus informations on the lags of the instrumented variables.
} 
(5) suggests that a one percentage point increase in the corporate tax rate enlarges the labour-to-capital-ratio by 1.6 per cent. Moreover, in specifications (6) and (7), we additionally account for dynamic patterns in the adjustments of the labour-to-capitalratio and reestimate the regressions (4) and (5) in an Arellano and Bond (1991) GMM framework including a lagged dependent variable which leaves the coefficient estimate for the corporate tax rate variable largely unaltered. ${ }^{18}$ Quantitatively, specification (7) suggests that a one percentage point increase in the corporate tax rate raises the labour to capital ratio by 1.5 per cent in the short run and by 2.3 per cent in the long run.

Again, we reestimate the specifications presented in Table 5a employing the tax rate differential to other group affiliates as a tax measure. The results are presented in Table $5 \mathrm{~b}$ and yield that the labour intensity of production rises in the corporate tax rate differential to other group affiliates. The results are hence in line with the notion that multinational groups tend to locate their labor intensive investment projects in high-tax affiliates within the group and vice versa. Specification (7) suggests that an increase in the corporate tax rate by one percentage point raises the labour-to-fixed asset-ratio by 0.4 per cent in the short run and 0.57 in the long run.

- Tables 5a and 5b here -

In Tables $6 \mathrm{a}$ and $6 \mathrm{~b}$, we reassess the effect of corporate taxes on the labour intensity by using the payroll-to-capital-ratio as the dependent variable. The results reported in Table 6a suggest that the corporate tax rate exerts a significantly positive effect on the payroll-to-capital-ratio which is robust against controlling for time-varying country controls, industry-year fixed effects, affiliate size and affiliate profitability. Moreover, the effect equally appears if we estimate a dynamic GMM model as indicated by specifications (6) and (7). Compared to the regressions which use the labour-to-fixed assetratio as the dependent variable, the coefficient estimates for the corporate tax rate variable are quantitatively smaller. Specification (7) suggests that a one percentage

\footnotetext{
${ }^{18}$ Using the GMM approach again implies that the sample size drops, see footnote 16.
} 
point increase in the corporate tax rate raises the payroll-to-capital-ratio by 0.7 per cent in the short run and by 1.1 per cent in the long run. Somewhat weaker results are found if we regress the payroll-to-capital-ratio on the tax rate differential between the affiliates and other firms in the multinational group as presented in Table 6b. The coefficient estimate for the tax difference variable does not gain statistical significance in the static regressions unless we include firm profitability as a control variable in Specification (5). Reestimating specification (5) in a dynamic model dampens the coefficient estimate for the tax differential which now just fails to be statistically significant at the 10 per cent level. Nevertheless, dropping small firms with less than 50 employees from the regression (which are expected to react the least sensitively to tax rate changes) quantitatively increases the coefficient estimate and renders it statistically significant at the 5 per cent level as reported in specification (7).

The fact that the corporate tax effects on payroll-intensity fall short from the labourintensity estimates suggests that taxes exert a negative impact on the average wage rate earned by the affiliate's workers which is in line with previous findings in the literature (see Arulampalam et al., 2007). This result is confirmed in Table 7 where we regress the logarithm of the average worker's wage level on the corporate tax rate and find a significant and negative effect which suggests that part of the additional tax burden on multinational firms is in fact borne by the multinationals' employees. Note in this context that the corporate tax effect on the labour-to-capital-ratio is not driven by this wage adjustment as we control for workers' wages in the specifications presented in Tables $5 \mathrm{a}$ and $5 \mathrm{~b}$.

- Tables $6 \mathrm{a}$ and $6 \mathrm{~b}$ here -

\section{Discussion of the results}

Our estimations indicate that corporate taxation does not only exert a negative effect on the quantity of capital investment but also affect the quality of corporate investment 
projects located in a country. We find that corporate taxation reduces profitability and increases 'payroll intensity' of investment. Plugging in our coefficient estimates from column (7) in Table 3, column (7) in Table 4a and Column (7) in Table 6a yields the following semielasticities: An increase in the corporate tax rate by one percentage point reduces the quantity of investment by 1.82 per cent $\left(\varepsilon_{k}=\frac{\gamma_{2}^{k}}{1-\gamma_{1}^{k}}=-1.82\right)$. The profit per unit of investment declines by 1.27 per cent $\left(\varepsilon_{b}=\gamma_{2}^{b}=-1.27\right)$ and the labour income generated per unit of investment increases by 1.06 per cent $\left(\varepsilon_{p}=\frac{\gamma_{2}^{p}}{1-\gamma_{1}^{p}}=1.06\right)$.

What does this imply for the overall effects of corporate tax changes on the profit tax base and on payroll? Note that, with $B=b k$, the semi-elasticity of the corporate tax base with respect to the corporate tax rate can be written as

$$
\frac{\partial B}{\partial t} \frac{1}{B}=\frac{\partial k}{\partial t} \cdot \frac{b}{B}+\frac{\partial b}{\partial t} \cdot \frac{k}{B}=\varepsilon_{k}+\varepsilon_{b}=-1.82-1.27=-3.09
$$

An increase in the corporate tax rate by one percentage point is predicted to lower the corporate tax base by 3.1 per cent. Quantity and quality effect are found to significantly contribute to this result, with the quality effect accounting for 42 per cent of the overall effect.

Similarly, using $P=p k$, we can calculate the effect on payroll as

$$
\frac{\partial P}{\partial t} \frac{1}{P}=\frac{\partial k}{\partial t} \cdot \frac{p}{P}+\frac{\partial p}{\partial t} \cdot \frac{k}{P}=\varepsilon_{k}+\varepsilon_{p}=-1.82+1.06=-0.76
$$

Thus, while corporate tax increases drive investment out of the country and consequently diminish payroll, this negative quantity effect is mitigated, albeit not reversed, by a positive quality effect which suggests that labour partly substitutes for capital investment. The estimations suggest that the quality effect compensates around 58 per cent $(1.06 /(-1.82)=-0.58)$ of the negative quantity impact on payroll. The overall semi-elasticity is calculated with -0.76 , i.e. increasing the corporate tax rate by one percentage point reduces the labour tax base by 0.76 per cent on average. ${ }^{19}$

\footnotetext{
${ }^{19}$ Note that the sample size differs across the specifications used to evaluate quantity and quality effects of corporate taxation against each other which is driven by the differing regression requirements
} 
For illustrative purposes, it is interesting to use these results in the formula for the optimal tax rate in (3). Consider firstly the case where the government ignores the quality effects of corporate taxation. Equation (3) then reads

$$
t_{0}^{c *}=0.55-\frac{\alpha(1-s)}{(\eta-\phi)} \frac{p}{b}-\frac{\phi}{(\eta-\phi)}
$$

Under the extreme assumptions that all firms are foreign owned $(\phi=0)$ and that a job loss in the international sector in our model will immediately be compensated by the creation of a job in the rest of the economy $(s=1)$, the optimal corporate income tax rate is equal to 55 per cent. If these assumptions are relaxed, a lower rate is optimal. Assume instead that $s=0.8$, i.e. a loss of labour income of 1 Euro in the industrial sector can only be replaced by an increase in income in the service sector of 80 Cents. Assume further that the share of domestic households in firm ownership $(\phi)$ is still zero, the payroll tax $\left(t^{p}\right)$ is 50 per cent, the marginal cost of public funds $(\eta)$ is 1.25 , and the payroll-profit ratio in the industrial sector $(p / b)$ is $2 / 1$. In this case, the optimal tax rate is equal to 19 per cent.

Now, assume that the government takes account of quality effects. The optimal tax rate reads

$$
t_{1}^{c *}=0.32-\frac{\alpha(1-s)}{(\eta-\phi)} \frac{p}{b} 0.25-\frac{\phi}{(\eta-\phi)}
$$

With $\phi=0$ and $s=1$, the optimal tax rate is equal to 32 per cent, compared to 55 per cent in the case where the government ignores quality effects of corporate taxation. Thus, taking into account the impact of corporate taxation on the quality of investment leads to lower optimal corporate tax rates. Interestingly, the picture changes, if we consider the second scenario with $s=0.8$. Then, the optimal tax rate with quality and quantity effects equals 23 per cent, compared to 19 per cent if quality effects are ignored.

concerning the availability of lagged variables in the specifications (see also footnotes 16, 17 and 18). In a robustness check, we constructed a subsample of observations which are included in all three specifications and find comparable results. 
Thus, in the first scenario with $s=1$, neglecting quality effects increases the optimal tax rate, while in the second scenario with $s=0,8$, neglecting quality effects reduces the optimal corporate tax rate. The reason is that, in the first scenario, the payroll effects do not play a role because each loss in labour income in the industrial sector is offset by a corresponding gain in the service sector. Only the tax effects on profitability have to be taken into account. In the second scenario, losses in labour income due to lower investment quantity or quality cannot be fully compensated. Then, the quality effect in terms of labour income generated per unit of investment acts as a break on tax cuts. Note that, although the example assumes that 80 per cent of the labour income lost in the international sector is replaced by employment in the service sector, the quality effect on employment is strong enough to overcompensate the quality effect in terms of contributing to the corporate income tax base. This suggests that much greater emphasis should be placed on investigating whether foreign direct investment increases labour income generated in the host country.

\section{Concluding remarks}

Governments throughout the world have lowered corporate tax rates in order to attract FDI. In this paper, we argue that taxes do not only affect the quantity of FDI but also the extent to which FDI contributes to corporate tax revenue and labour income, i.e. the quality of FDI. We use detailed data on European multinational firms to empirically measure quantity and quality effects of corporate taxation on FDI. With regard to quantity effects, we find a semi-elasticity of the capital stock to corporate tax rate changes of approximately -2 , which is in line with the results of previous studies. In terms of quality effects, our results suggest that corporate taxation substantially lowers the profitability of corporate investment projects and increases the labour intensity of production. The importance of tax effects on investment quality can be illustrated by considering how taxes affect the corporate tax base or labour income in general. With regard to the corporate tax base, our findings suggests that only around 60 per cent of 
the corporate tax base reduction in the wake of tax increases is driven by a decline in investment size while the other 40 per cent are assigned to a diminishing profitability of the investment projects. With regard to the multinational's payroll, the estimations suggest that the quality effect compensates around 58 per cent of the negative quantity impact.

These results may have important policy implications. If taxes equally distort the quality and the quantity of FDI, measures of investment distortions based on investment quantity are likely to misrepresent the efficiency cost of taxation. Moreover, it suggests that policy-makers should not only be concerned about the size of FDI inflows but equally about the profitability of the incoming projects. Thus, our results may alter the interpretation of certain "success stories". For example, from 1990 to 2000, Germany increased its stock of foreign held capital by about 520 per cent (source: OECD) and performed much better in attracting foreign FDI than the UK (115 per cent), France (205 per cent), the US (180 per cent) or Japan (410 per cent). The standard way of reading these figures is that Germany attracted FDI despite its relatively high tax rates (before the tax reform in 2001, the corporate tax rates in Germany were between 52 and 58 per cent and thus among the highest throughout the developed world). In the light of our results, one would expect these large inflows of capital to be of minor quality in the profitability dimension but of higher quality in terms of generating labour income.

\section{References}

[1] Arulampalam W., Devereux, M.P. \& Maffini, G. (2007). The Indirect Incidence of Corporate Income Tax on Wages, CBT Working Paper 07/07.

[2] Anderson, T. W. \& Hsiao, C. (1982). Formulation and Estimation of Dynamic Models Using Panel Data, Journal of Econometrics 18(1): 47-82. 
[3] Arellano, M. \& Bond, S. R. (1991). Some Test of Specification for Panel Data: Monte Carlo Evidence and an Application to Employment Equations, Review of Economic Studies 58(2): 277-297.

[4] Becker, J.\& Fuest, C. (2007). Quantity versus Quality - the composition effect of corporate taxation on foreign direct investment, CESifo Working Paper No. 2126.

[5] Bernard, A. B. \& Jensen, J. B. (2007). Firm Structure, Multinationals, and Manufacturing Plant Deaths, Review of Economics \& Statistics 89(2): 193-204.

[6] Bernard, A. B., Jensen, J. B., Redding, S. J. \& Schott, P. K. (2007). Firms in International Trade, Journal of Economic Perspectives 21(3): 105-130.

[7] de Mooij, R. \& Ederveen, S. (2003). Taxation and Foreign Direct Investment: A Synthesis of Empirical Research, International Tax and Public Finance 10(6): 673-693.

[8] Devereux, M.P., Griffith, R. \& Klemm, A. (2002). Corporate income tax reforms and international tax competition, Economic Policy 17(35): 450-495.

[9] Devereux, M.P. and R. Griffith (2003), Evaluating Tax Policy for Location Decisions, International tax and Public Finance 10, 107-126.

[10] Devereux, M. P. (2007). The Impact of Taxation on the Location of Capital, Firms and Profit: A Survey of Empirical Evidence, Oxford University Centre for Business Taxation Working Paper Series No. 07/2.

[11] Dischinger, M. (2008). Profit Shifting by Multinationals and the Ownership Share: Evidence from European Micro Data, Munich Economics Discussion Papers, No. 2008-17.

[12] Dischinger, M. \& Riedel, N. (2008). Corporate Taxes, Profit Shifting, and the Location of Multinational Headquarters, Working Paper. 
[13] Dwenger, N. \& Steiner, V. (2008). Effective Profit Taxation and the Elasticity of the Corporate Income Tax Base: Evidence from German Corporate Tax Return Data, DIW Discussion Paper No. 829.

[14] European Commission (2006). Structures of the Taxation Systems in the European Union, Directorate Generale Taxation and Customs Union, Brussels.

[15] Grossman, G. M. \& Rossi-Hansberg, E. (2008). Trading Tasks: A Simple Theory of Offshoring, American Economic Review 98(5): 1978-1997.

[16] Gruber, J. \& Rauh, J. (2007). How Elastic Is the Corporate Income Tax Base? in: Auerbach, A. J. et al. (eds.): Taxing Corporate Income in the 21st Century, 2007, Cambridge and New York: Cambridge University Press, 140-63.

[17] Grubert, H. \& Mutti, J. H. (1991). Taxes, Tariffs and Transfer Pricing in Multinational Corporate Decision Making, Review of Economics and Statistics 73: 285293.

[18] Hanlon, M. \& Maydew, E. L. (2009). Book-tax Conformity: Implications for Multinational Firms, National Tax Journal 72(1), pp. 127-153.

[19] Haufler, A. and F. Stahler (2009), Tax Competition in a Simple Model with Heterogeneous Firms, How Larger Markets reduce Profit Taxes, CESifo Working Paper No 2687.

[20] Hines, J. R. \& Rice, E. M. (1994). Fiscal Paradise: Foreign Tax Havens and American Business, Quarterly Journal of Economics 109(1): 149-182.

[21] Huizinga, H. \& Laeven, L. (2008). International Profit Shifting Within European Multinationals, Journal of Public Economics, 92(5/6): 1164-1182.

[22] KPMG (2006). Corporate Tax Rate Survey, KPMG International, United Kingdom. 
[23] Loretz (2008). Corporate Taxation in the OECD in a Wider Context, Oxford Review of Economic Policy 24(4), 639-660.

[24] Weichenrieder, A. J. (forthcoming). Profit Shifting in the EU: Evidence from Germany, International Tax and Public Finance.

\section{Tables}

\begin{tabular}{|l|c|}
\hline \multicolumn{2}{|l|}{ Table 1: Country Statistics } \\
\hline \hline Country & Affiliates \\
\hline Austria & 282 \\
Belgium & 2,079 \\
Czech Republic & 531 \\
Denmark & 1,782 \\
Finland & 572 \\
France & 2,839 \\
Germany & 1,435 \\
Great Britain & 4,053 \\
Greece & 143 \\
Hungary & 35 \\
Ireland & 213 \\
Island & 8 \\
Italy & 2,358 \\
Luxembourg & 23 \\
Netherlands & 2,561 \\
Norway & 1,124 \\
Poland & 1,051 \\
Portugal & 277 \\
Spain & 2,669 \\
Slovakia & 84 \\
Sweden & 2,214 \\
Switzerland & 140 \\
\hline Sum & 26,473 \\
\hline
\end{tabular}


Table 2: Descriptive Statistics

\begin{tabular}{|c|c|c|c|c|c|}
\hline Variable & Obs. & Mean & Std.Dev. & Min. & Max. \\
\hline \multicolumn{6}{|l|}{ Affiliate Characteristics } \\
\hline Fixed Assets $\star$ & 101,059 & $165,952.5$ & $1,610,977$ & 1 & $1.05 \mathrm{e}+08$ \\
\hline Sales $\star$ & 92,571 & $195,835.5$ & $1,536,974$ & 1 & $1.46 \mathrm{e}+08$ \\
\hline Number of Employees & 101,059 & 543.700 & $3,568.289$ & 1 & 99,837 \\
\hline Costs of Employees $\star$ & 95,636 & $26,474.24$ & $185,304.8$ & 1 & $1.11 \mathrm{e}+07$ \\
\hline Avg. Yearly Wage & 95,636 & 62.488 & 46.732 & .005 & 450.615 \\
\hline Profit before Tax $\star$ & 101,059 & $19,175.1$ & $191,824.7$ & 1 & $1.16 \mathrm{e}+07$ \\
\hline Profitability (Pre-Tax Profit per Total Assets) & 101,059 & .1264 & .8140 & 1 & 219.2168 \\
\hline Labour-Fixed Asset Ratio & 101,059 & .1436 & 1.9360 & $5.49 \mathrm{e}-08$ & 481.1111 \\
\hline Payroll-Fixed Assets Ratio & 95,636 & 8.1375 & 100.3023 & $2.97 \mathrm{e}-06$ & 19,509 \\
\hline \multicolumn{6}{|l|}{ Country Characteristics } \\
\hline Corporate Tax Rate & 101,059 & .3246 & .0477 & .1 & .516 \\
\hline Tax Difference Group & 86,623 & .0061 & .0651 & -.3113 & .356 \\
\hline EMTR & 95,871 & .1131 & .0406 & .0091 & .1727 \\
\hline Marginal Labour Tax Rate ${ }^{\dagger}$ & 101,059 & .5210 & .0842 & .33 & .77 \\
\hline PV Capital Allowances & 101,059 & .6604 & .0540 & .5344 & .7458 \\
\hline GDP` & 101,059 & 990.2577 & 782.1834 & 8.953 & $2,914.988$ \\
\hline GDP per Capita & 101,059 & $30,250.75$ & $11,206.31$ & $3,768.026$ & $74,471.23$ \\
\hline Corruption Index & 101,059 & 7.5199 & 1.6447 & 3.4 & 10 \\
\hline Unemployment Rate & 101,059 & .0752 & .0329 & .018 & .199 \\
\hline
\end{tabular}

$\underline{\text { Notes: }}$

$\star$ Unconsolidated value, in thousand US dollars, current prices.

\ In billion US dollars, current prices.

4 In US dollars, current prices.

$\dagger$ Marginal tax wedge for worker with the mean income. 


\begin{tabular}{|c|c|c|c|c|c|c|c|c|}
\hline \multicolumn{9}{|c|}{$\begin{array}{l}\text { Table 3: Quantity Effect - Impact of Taxes on Corporate Investment } \\
\text { Dep. Variable: Log Fixed Asset Investment, Panel 2000-2006 }\end{array}$} \\
\hline Model & \multicolumn{4}{|c|}{ Fixed Effects Model } & \multicolumn{4}{|c|}{ GMM Model } \\
\hline Explanat. Var.: & (1) & (2) & (3) & (4) & (5) & (6) & (7) & (8) \\
\hline Lag Log Fixed Assets & & & & & $\begin{array}{l}.377^{* * *} \\
(.064)\end{array}$ & $\begin{array}{l}.344^{* * *} \\
(.066)\end{array}$ & $\begin{array}{l}.384^{* * *} \\
(.059)\end{array}$ & $\begin{array}{l}.384^{* * *} \\
(.060)\end{array}$ \\
\hline Stat. Corporate Tax & $\begin{array}{c}-1.584^{* * *} \\
(.222)\end{array}$ & $\begin{array}{c}-1.452^{* * *} \\
(.221)\end{array}$ & $\begin{aligned}-1.449^{* * * *} \\
(.225)\end{aligned}$ & & $\begin{array}{c}-1.180^{* * *} \\
(.159)\end{array}$ & $\begin{array}{c}-1.097^{* * * *} \\
(.158)\end{array}$ & $\begin{array}{c}-1.122^{* * *} \\
(.161)\end{array}$ & \\
\hline EMTR & & & & $\begin{array}{c}-1.882^{* * *} \\
(.315)\end{array}$ & & & & $\begin{array}{r}-1.500^{* * *} \\
(.238)\end{array}$ \\
\hline Log GDP pC & & $\begin{array}{l}.949^{* * *} \\
(.102)\end{array}$ & $\begin{array}{c}1.023^{* * *} \\
(.104)\end{array}$ & $\begin{array}{c}1.351^{* * *} \\
(.104)\end{array}$ & & $\begin{array}{l}.546^{* * * *} \\
(.091)\end{array}$ & $\begin{array}{l}.550^{* * *} \\
(.092)\end{array}$ & $\begin{array}{l}.656^{* * * *} \\
(.096)\end{array}$ \\
\hline Log GDP & & $\begin{array}{l}.073 \\
(.048)\end{array}$ & $\begin{array}{l}.061 \\
(.049)\end{array}$ & $\begin{array}{l}.033 \\
(.037)\end{array}$ & & $\begin{array}{l}.020 \\
(.020)\end{array}$ & $\begin{array}{l}.020 \\
(.022)\end{array}$ & $\begin{array}{l}.021 \\
(.020)\end{array}$ \\
\hline Corruption & & $\begin{array}{c}-.185^{* * *} \\
(.067)\end{array}$ & $\begin{array}{l}-.183 \\
(.069)\end{array}$ & $\begin{array}{l}-.027 \\
(.070)\end{array}$ & & $\begin{array}{l}-.120 \\
(.051)\end{array}$ & $\begin{array}{c}-.123^{* * *} \\
(.054)\end{array}$ & $\begin{array}{l}-.069 \\
(.055)\end{array}$ \\
\hline Unemp. Rate & & $\begin{array}{l}-.599^{*} \\
(.353)\end{array}$ & $\begin{array}{c}-.750^{* *} \\
(.359)\end{array}$ & $\begin{array}{l}-.178 \\
(.370)\end{array}$ & & $\begin{array}{l}.163 \\
(.285)\end{array}$ & $\begin{array}{c}.063 \\
(.029)\end{array}$ & $\begin{array}{l}.053 \\
(.293)\end{array}$ \\
\hline PV Capital Allowances & & & $\begin{array}{c}.004 \\
(.367)\end{array}$ & & & & $\begin{array}{c}.417 \\
(.304)\end{array}$ & \\
\hline $\begin{array}{l}\text { Year D. } \\
\text { Industry-Year D. }\end{array}$ & $\sqrt{ }$ & $\sqrt{ }$ & $\begin{array}{l}\checkmark \\
\sqrt{ }\end{array}$ & $\begin{array}{l}\sqrt{ } \\
\sqrt{ }\end{array}$ & $\sqrt{ }$ & $\sqrt{ }$ & $\begin{array}{l}\checkmark \\
\sqrt{ }\end{array}$ & $\begin{array}{l}\checkmark \\
\checkmark\end{array}$ \\
\hline Sargan/Hansen & - & - & - & - & 0.811 & 0.770 & 0.762 & 0.875 \\
\hline AR(2) Test & - & - & - & - & 0.328 & 0.286 & 0.666 & 0.777 \\
\hline \# Obs. & 101,059 & 101,059 & 100,697 & 95,509 & 66,452 & 66,335 & 66,148 & 62,656 \\
\hline \# Firms & 26,473 & 26,473 & 26,332 & 25,060 & 19,421 & 19,412 & 19,338 & 18,265 \\
\hline$R^{2}$ Within & 0.1217 & 0.1255 & 0.1301 & 0.1328 & - & - & - & - \\
\hline
\end{tabular}

Notes:

Heteroskedasticity robust standard errors adjusted for firm clusters in parentheses. ${ }^{*},{ }^{* *},{ }^{* * *}$ indicates significance at the $10 \%, 5 \%, 1 \%$ level. The observational units are multinational affiliates per sample year. All regressions include a full set of firm fixed effects. The dependent variable is the logarithm of a affiliates's fixed asset investment. In specifications (1) to (4) a fixed effect model is estimated while specifications (5) to (8) estimate a dynamic first difference GMM model as proposed by Arellano and Bond (1991). Sargan/Hansen indicates the p-value of the Sargan-Hansen overidentification test. AR(2) Test depicts the p-value for the test of second order autocorrelation. Lag Log Fixed Assets depicts the first lag of the dependent variable, i.e. the logarithm of the affiliate's fixed assets. Stat. Corporate Tax stands for the host country's statutory corporate tax rate and EMTR for its effective marginal tax rate. Log GDP and $\log G D P p C$ indicate the logarithm of the host country's gross domestic product and gross domestic product per captita. Corruption is an index for the host country's corruption level, Unemp. Rate stands for the unemployment rate, PV Capital Allowances for the present value of capital allowances for corporate taxation, Year D. for a full set of year dummies and Industry-Year D. for a full set of two-digit industry-year dummies. 


\begin{tabular}{|c|c|c|c|c|c|c|c|}
\hline \multicolumn{8}{|c|}{$\begin{array}{l}\text { Table 4a: Quality Effect - Impact of Taxes on Investment Profitability } \\
\text { Dep. Variable: Log of Pre-tax Profitability, Panel 2000-2006 }\end{array}$} \\
\hline \multirow{2}{*}{$\begin{array}{l}\text { Dep. Variable } \\
\text { Explanat. Var.: }\end{array}$} & \multicolumn{5}{|c|}{ Pre-tax Profit per Total Assets } & \multicolumn{2}{|c|}{ Pre-tax Profit per Fixed Assets } \\
\hline & (1) & (2) & (3) & (4) & (5) & (6) & $(7)$ \\
\hline \multirow[t]{2}{*}{ Corporate Tax Rate } & $-1.247^{* * *}$ & $-1.104^{* * *}$ & $-1.163^{* * *}$ & $-1.252^{* * *}$ & $-1.347^{* * *}$ & $-1.237^{* * *}$ & $-1.272^{* * *}$ \\
\hline & $(.260)$ & $(.262)$ & $(.263)$ & $(.283)$ & $(.496)$ & $(.296)$ & $(.489)$ \\
\hline \multirow[t]{2}{*}{ Log GDP p. C. } & & $.410^{* * *}$ & $.367^{* *}$ & $.380^{* *}$ & .506 & $.341^{*}$ & -.097 \\
\hline & & $(.181)$ & $(.180)$ & $(.164)$ & $(1.259)$ & $(.179)$ & $(1.225)$ \\
\hline \multirow[t]{2}{*}{ Log GDP } & & $-.290^{* * *}$ & $-.285^{* *}$ & $-.226^{* *}$ & -.731 & -.219 & -.262 \\
\hline & & $(.135)$ & $(.133)$ & $(.108)$ & $(1.232)$ & $(.121)$ & $(1.199)$ \\
\hline \multirow[t]{2}{*}{ Corruption Index } & & .111 & .126 & .093 & .240 & .022 & .126 \\
\hline & & $(.088)$ & $(.090)$ & $(.094)$ & $(.203)$ & $(.098)$ & $(.200)$ \\
\hline \multirow[t]{2}{*}{ Unempl. Rate } & & $2.625^{* * *}$ & $2.523^{* * *}$ & $3.297^{* * *}$ & $2.129^{* * *}$ & $3.564^{* * *}$ & $2.699^{* * *}$ \\
\hline & & $(.418)$ & $(.422)$ & $(.443)$ & $(.839)$ & $(.472)$ & $(.815)$ \\
\hline \multirow[t]{2}{*}{ Log Labour Intensity } & & & & $.142^{* * *}$ & $.408^{*}$ & $.137^{* * *}$ & $1.061^{* * *}$ \\
\hline & & & & $(.008)$ & $(.216)$ & $(.016)$ & $(.209)$ \\
\hline \multirow[t]{2}{*}{ Log Sales } & & & & $.210^{* * *}$ & $-1.106^{* * *}$ & $.818^{* * *}$ & $-.872^{* * *}$ \\
\hline & & & & $(.014)$ & $(.292)$ & $(.010)$ & $(.285)$ \\
\hline Year D. & $\sqrt{ }$ & $\sqrt{ }$ & $\sqrt{ }$ & $\sqrt{ }$ & $\sqrt{ }$ & $\sqrt{ }$ & $\sqrt{ }$ \\
\hline Industry-Year D. & & & $\sqrt{ }$ & $\sqrt{ }$ & $\sqrt{ }$ & $\sqrt{ }$ & $\sqrt{ }$ \\
\hline Model & $\mathbf{F E}$ & FE & $\mathbf{F E}$ & FE & IV & $\mathbf{F E}$ & IV \\
\hline Sargan/Hansen & - & - & - & - & 0.176 & - & 0.173 \\
\hline Kleinbergen/Paap & - & - & - & - & 0.000 & - & 0.000 \\
\hline \# Observations & 101,059 & 101,059 & 100,697 & 88,776 & 31,244 & 88,776 & 31,245 \\
\hline \# Firms & 26,473 & 26,473 & 26,332 & 23,046 & 12,091 & 23,046 & 12,091 \\
\hline$R^{2}$ Within & 0.0053 & 0.0063 & 0.0073 & 0.0313 & - & 0.2568 & - \\
\hline
\end{tabular}

Notes:

Heteroskedasticity robust standard errors adjusted for firm clusters in parentheses. ${ }^{*},{ }^{* *},{ }^{* * *}$ indicates significance at the $10 \%, 5 \%, 1 \%$ level. The observational unit is the multinational affiliate per sample year. The dependent variable is the logarithm of the affiliate's pre-tax profits per total assets (fixed assets) in Specifications (1) to (5) (in Specifications (6) to (7)). In Specifications (1)-(4) and (6) a fixed effect model is estimated while Specifications (5) and (7) estimate a first difference model which accounts for the potential reverse causality between affiliate profitability and fixed asset investment and employment intensity by using an instrumental variable approach. Sargan/Hansen depicts the p-value of the Sargan/Hansen overidentification test. Kleinbergen-Paap stands for the Kleinbergen-Paap Statistic which tests the revelevance of the instrument set employed. Stat. Corporate Tax stands for the host country's statutory corporate tax rate and EMTR for its effective marginal tax rate. $\log G D P$ and $\log G D P p C$ indicate the logarithm of the host country's gross domestic product and gross domestic product per captita. Corruption is an index for the host country's corruption level, Unemp. Rate stands for the unemployment rate, PV Capital Allowances for the present value of capital allowances for corporate taxation, Year D. for a full set of year dummies and Industry-Year D. for a full set of two-digit industry-year dummies. Moreover, Log Labour Intensity depicts the logarithm of the labour intensity as measured by the logarithm of the payroll sum over fixed assets and Log Sales is the logarithm of the affiliate's sales which proxies for the firm's size. 
Table 4b: Quality Effect - Impact of Taxes on Investment Profitability

Dep. Variable: Log of Pre-tax Profitability, Panel 2000-2006

\begin{tabular}{|c|c|c|c|c|c|c|c|}
\hline \multirow{2}{*}{$\begin{array}{l}\text { Dep. Variable } \\
\text { Explanat. Var.: }\end{array}$} & \multicolumn{5}{|c|}{ Pre-tax Profit per Total Assets } & \multicolumn{2}{|c|}{ Pre-tax Profit per Fixed Assets } \\
\hline & (1) & (2) & (3) & (4) & (5) & (6) & (7) \\
\hline \multirow[t]{2}{*}{ Tax Differential } & $-.927^{* * *}$ & $-.853^{* * *}$ & $-.863^{* * *}$ & $-.760^{* * *}$ & $-1.115^{* * *}$ & $-.768^{* * *}$ & $-1.109^{* * *}$ \\
\hline & $(.179)$ & $(.179)$ & $(.179)$ & $(.189)$ & $(.361)$ & $(.198)$ & $(.362)$ \\
\hline \multirow{2}{*}{ Log GDP p. C. } & & $.537^{* * *}$ & $.493^{* * *}$ & $.470^{* *}$ & 2.149 & $.510^{* * *}$ & 1.521 \\
\hline & & $(.181)$ & $(.185)$ & $(.175)$ & $(1.341)$ & $(.188)$ & $(1.350)$ \\
\hline \multirow[t]{2}{*}{ Log GDP } & & $-.314^{* * *}$ & $-.308^{* *}$ & $-.253^{* *}$ & -1.960 & $-.243^{* *}$ & -1.401 \\
\hline & & $(.138)$ & $(.133)$ & $(.114)$ & $(1.275)$ & $(.124)$ & $(1.284)$ \\
\hline \multirow[t]{2}{*}{ Corruption Index } & & .175 & .189 & .167 & .315 & .125 & .256 \\
\hline & & $(.093)$ & $(.094)$ & $(.099)$ & $(.204)$ & $(.102)$ & $(.204)$ \\
\hline \multirow[t]{2}{*}{ Unempl. Rate } & & $2.755^{* * *}$ & $2.635^{* * *}$ & $3.337^{* * *}$ & $2.674^{* * *}$ & $3.646^{* * *}$ & $3.137^{* * *}$ \\
\hline & & $(.444)$ & $(.448)$ & $(.471)$ & $(.897)$ & $(.501)$ & $(.898)$ \\
\hline \multirow[t]{2}{*}{ Log Labour Intensity } & & & & $.207^{* * *}$ & $.590^{* * *}$ & $.801^{* * *}$ & $1.272^{* * *}$ \\
\hline & & & & $(.015)$ & $(.230)$ & $(.011)$ & $(.229)$ \\
\hline \multirow[t]{2}{*}{ Log Sales } & & & & $.211^{* * *}$ & $-.684^{* *}$ & $.135^{* * *}$ & $-.570^{*}$ \\
\hline & & & & $(.014)$ & $(.314)$ & $(.017)$ & $(.316)$ \\
\hline Year D. & $\sqrt{ }$ & $\sqrt{ }$ & $\sqrt{ }$ & $\sqrt{ }$ & $\sqrt{ }$ & $\sqrt{ }$ & $\sqrt{ }$ \\
\hline Industry-Year D. & & & $\sqrt{ }$ & $\sqrt{ }$ & $\sqrt{ }$ & $\sqrt{ }$ & $\sqrt{ }$ \\
\hline Model & FE & FE & FE & FE & IV & FE & IV \\
\hline Sargan/Hansen & - & - & - & - & 0.5204 & - & - \\
\hline Kleinbergen/Paap & - & - & - & - & 0.000 & - & - \\
\hline \# Observations & 86,623 & 86,623 & 86,297 & 76,076 & 25,519 & 76,076 & 25,520 \\
\hline \# Firms & 22,114 & 22,114 & 21,992 & 19,202 & 9,603 & 19,202 & 9,603 \\
\hline$R^{2}$ Within & 0.0056 & 0.0069 & 0.0082 & 0.0307 & - & 0.2434 & - \\
\hline
\end{tabular}

Notes:

Heteroskedasticity robust standard errors adjusted for firm clusters in parentheses. ${ }^{*},{ }^{* *},{ }^{* * *}$ indicates significance at the $10 \%, 5 \%, 1 \%$ level. The observational unit is the multinational affiliate per sample year. The dependent variable is the logarithm of the affiliate's pre-tax profits per total assets (fixed assets) in Specifications (1) to (5) (in Specifications (6) to (7)). In Specifications (1)-(4) and (6) a fixed effect model is estimated while Specifications (5) and (7) estimate a first difference model which accounts for the potential reverse causality between affiliate profitability and fixed asset investment and employment intensity by using an instrumental variable approach. Sargan/Hansen depicts the p-value of the Sargan/Hansen overidentification test. Kleinbergen-Paap stands for the Kleinbergen-Paap Statistic which tests the revelevance of the instrument set employed. Tax Differential stands for the unweighted average difference between the host country's statutory corporate tax rate and the statutory corporate tax rate of other firms within the multinational group. $E M T R$ is the affiliate's effective marginal tax rate. $\log G D P$ and $\log G D P p C$ indicate the logarithm of the host country's gross domestic product and gross domestic product per captita. Corruption is an index for the host country's corruption level, Unemp. Rate stands for the unemployment rate, PV Capital Allowances for the present value of capital allowances for corporate taxation, Year D. for a full set of year dummies and Industry-Year D. for a full set of two-digit industry-year dummies. Moreover, Log Labour Intensity depicts the logarithm of the labour intensity as measured by the logarithm of the payroll sum over fixed assets and Log Sales is the logarithm of the affiliate's sales which proxies for the firm's size. 


\begin{tabular}{|c|c|c|c|c|c|c|c|}
\hline \multicolumn{8}{|c|}{$\begin{array}{c}\text { Table 5a: Quality Effect - Impact of Taxes on Labour Intensity } \\
\text { Dep. Variable: Log Labour Intensity, Panel 2000-2006 }\end{array}$} \\
\hline Model & \multicolumn{5}{|c|}{ Fixed Effects Model } & \multicolumn{2}{|c|}{ GMM Model } \\
\hline Explanat. Var.: & (1) & (2) & (3) & (4) & (5) & (6) & (7) \\
\hline Lag Labour Int. & & & & & & $\begin{array}{l}.409^{* * *} \\
(.065)\end{array}$ & $\begin{array}{l}.303^{* * *} \\
(.068)\end{array}$ \\
\hline Corporate Tax Rate & $\begin{array}{l}1.630^{* * *} \\
(.230)\end{array}$ & $\begin{array}{l}1.649^{* * *} \\
(.230)\end{array}$ & $\begin{array}{c}1.566^{* * *} \\
(.230)\end{array}$ & $\begin{array}{c}1.675^{* * *} \\
(.239)\end{array}$ & $\begin{array}{c}1.556^{* * *} \\
(.199)\end{array}$ & $\begin{array}{c}1.679^{* * *} \\
(.203)\end{array}$ & $\begin{array}{c}1.584^{* * *} \\
(.232)\end{array}$ \\
\hline Log GDP per Capita & & $\begin{array}{c}-.428^{* * *} \\
(.108)\end{array}$ & $\begin{array}{c}-.519^{* * *} \\
(.110)\end{array}$ & $\begin{array}{c}-.589^{* * *} \\
(.112)\end{array}$ & $\begin{array}{r}-.448^{* * *} \\
(.108)\end{array}$ & $\begin{array}{c}-.590^{* * *} \\
(.106)\end{array}$ & $\begin{array}{r}-.666^{* * *} \\
(.156)\end{array}$ \\
\hline Log GDP & & $\begin{array}{l}-.067 \\
(.052)\end{array}$ & $\begin{array}{l}-.058 \\
(.054)\end{array}$ & $\begin{array}{l}-.057 \\
(.054)\end{array}$ & $\begin{array}{c}.013 \\
(.069)\end{array}$ & $\begin{array}{l}.009 \\
(.014)\end{array}$ & $\begin{array}{l}.030^{* *} \\
(.017)\end{array}$ \\
\hline Corruption Index & & $\begin{array}{l}.344^{* * *} \\
(.075)\end{array}$ & $\begin{array}{l}.341^{* * *} \\
(.076)\end{array}$ & $\begin{array}{c}.420 \\
(.078)\end{array}$ & $\begin{array}{c}.130 \\
(.062)\end{array}$ & $\begin{array}{l}.819^{* * *} \\
(.080)\end{array}$ & $\begin{array}{l}.674^{* * *} \\
(.193)\end{array}$ \\
\hline Unempl. Rate & & $\begin{array}{l}.931^{* * *} \\
(.378)\end{array}$ & $\begin{array}{l}.836^{* *} \\
(.379)\end{array}$ & $\begin{array}{c}.554 \\
(.385)\end{array}$ & $\begin{array}{c}-1.345^{* * *} \\
(.313)\end{array}$ & $\begin{array}{l}.061 \\
(.330)\end{array}$ & $\begin{array}{l}-.296 \\
(.340)\end{array}$ \\
\hline Labour Tax Rate & & & & $\begin{array}{l}-.013 \\
(.104)\end{array}$ & $\begin{array}{l}-.053 \\
(.088)\end{array}$ & $\begin{array}{l}.102 \\
(.098)\end{array}$ & $\begin{array}{l}.176^{*} \\
(.096)\end{array}$ \\
\hline PV Capital Allowances & & & & $\begin{array}{l}-.239 \\
(.428)\end{array}$ & $\begin{array}{c}-.986^{* * *} \\
(.304)\end{array}$ & $\begin{array}{l}1.127^{* *} \\
(.468)\end{array}$ & $\begin{array}{c}.735 \\
(.494)\end{array}$ \\
\hline Log Sales & & & & $\begin{array}{c}.083 \\
(.019)\end{array}$ & $\begin{array}{l}.080^{* * *} \\
(.016)\end{array}$ & $\begin{array}{l}.190^{* * *} \\
(.057)\end{array}$ & $\begin{array}{l}.325^{* * *} \\
(.096)\end{array}$ \\
\hline Log Wage & & & & & $\begin{array}{c}-.718^{* * *} \\
(.020)\end{array}$ & & $\begin{array}{l}-.232 \\
(.234)\end{array}$ \\
\hline Log Pre-tax Profitability & & & & & $\begin{array}{l}.286^{\text {*** }} \\
(.005)\end{array}$ & & $\begin{array}{l}.089^{* *} \\
(.042)\end{array}$ \\
\hline $\begin{array}{l}\text { Year D. } \\
\text { Industry-Year D. }\end{array}$ & $\sqrt{ }$ & $\sqrt{ }$ & $\begin{array}{l}\sqrt{ } \\
\sqrt{ }\end{array}$ & $\begin{array}{l}\sqrt{ } \\
\sqrt{ }\end{array}$ & $\begin{array}{l}\sqrt{ } \\
\sqrt{ }\end{array}$ & $\begin{array}{l}\sqrt{ } \\
\sqrt{ }\end{array}$ & $\begin{array}{l}\sqrt{ } \\
\sqrt{ }\end{array}$ \\
\hline $\begin{array}{l}\operatorname{AR}(2) \\
\text { Sargan/Hansen }\end{array}$ & & & & & & $\begin{array}{l}0.120 \\
0.794\end{array}$ & $\begin{array}{l}0.419 \\
0.643\end{array}$ \\
\hline \# Observations & 101,059 & 101,059 & 101,059 & 92,241 & 88,776 & 61,086 & 50,894 \\
\hline \# Firms & 26,473 & 26,473 & 26,473 & 24,034 & 23,046 & 17,735 & 15,389 \\
\hline$R^{2}$ Within & 0.0638 & 0.0654 & 0.0689 & 0.0786 & 0.3904 & - & - \\
\hline
\end{tabular}

Heteroskedasticity robust standard errors adjusted for firm clusters in parentheses. ${ }^{*},{ }^{* *},{ }^{* * *}$ indicates significance at the $10 \%, 5 \%, 1 \%$ level. The observational unit is the multinational affiliate per sample year. The dependent variable is the logarithm of the affiliate's labour-to-fixed asset-ratio. In specifications (1) to (5) a fixed effect model is estimated while specifications (6) to (7) estimate a dynamic first difference GMM model as proposed by Arellano and Bond (1991). Sargan/Hansen indicates the p-value of the Sargan-Hansen overidentification test. AR(2) depicts the p-value for the test of second order autocorrelation. Stat. Corporate Tax stands for the host country's statutory corporate tax rate and $E M T R$ for its effective marginal tax rate. $\log G D P$ and $\log G D P p C$ indicate the logarithm of the host country's gross domestic product and gross domestic product per captita. Corruption is an index for the host country's corruption level, Unemp. Rate stands for the unemployment rate, PV Capital Allowances for the present value of capital allowances for corporate taxation, Labour Tax Rate for the labour tax wedge of a person who earns the median country income, Year $D$. for a full set of year dummies and Industry-Year D. for a full set of two-digit industry-year dummies. Moreover, Log Sales is the logarithm of the affiliate's sales which proxies for the firm's size, Log Wage is the logarithm of the average affiliate worker's yearly wage rate and Log Pre-tax Profitability is the logarithm of the affiliate's pre-tax profitability as measured by pre-tax profits over fixed assets. 


\begin{tabular}{|c|c|c|c|c|c|c|c|}
\hline \multicolumn{8}{|c|}{$\begin{array}{c}\text { Table 5b: Quality Effect - Impact of Taxes on Labour Intensity } \\
\text { Dep. Variable: Labour Intensity, Panel 2000-2006 }\end{array}$} \\
\hline Model & & Fixe & Effects & Model & & GMM & Model \\
\hline Explanat. Var.: & (1) & (2) & (3) & (4) & (5) & (6) & (7) \\
\hline Lag Labour Int. & & & & & & $\begin{array}{l}.223^{* * *} \\
(.103)\end{array}$ & $\begin{array}{l}.244^{* * *} \\
(.064)\end{array}$ \\
\hline Tax Differential & $\begin{array}{l}.227 \\
(.147)\end{array}$ & $\begin{array}{l}.304^{* *} \\
(.146)\end{array}$ & $\begin{array}{l}.301^{* *} \\
(.147)\end{array}$ & $\begin{array}{l}.416^{* * *} \\
(.151)\end{array}$ & $\begin{array}{l}.404^{* * *} \\
(.124)\end{array}$ & $\begin{array}{l}.452^{* * *} \\
(.119)\end{array}$ & $\begin{array}{l}.432^{* * *} \\
(.122)\end{array}$ \\
\hline Log GDP per Capita & & $\begin{array}{c}-.372^{* * *} \\
(.107)\end{array}$ & $\begin{array}{c}-.475^{* * *} \\
(.109)\end{array}$ & $\begin{array}{c}-.543^{* * *} \\
(.111)\end{array}$ & $\begin{array}{c}-.425^{* * *} \\
(.107)\end{array}$ & $\begin{array}{c}-.739^{* * *} \\
(.109)\end{array}$ & $\begin{array}{c}-.710^{* * *} \\
(.158)\end{array}$ \\
\hline Log GDP & & $\begin{array}{l}-.030 \\
(.040)\end{array}$ & $\begin{array}{l}-.019 \\
(.045)\end{array}$ & $\begin{array}{l}-.019 \\
(.044)\end{array}$ & $\begin{array}{c}.040 \\
(.063)\end{array}$ & $\begin{array}{c}.015 \\
(.012)\end{array}$ & $\begin{array}{l}.042^{* *} \\
(.020)\end{array}$ \\
\hline Corruption Index & & $\begin{array}{l}.284^{* * *} \\
(.077)\end{array}$ & $\begin{array}{l}.295^{* * *} \\
(.078)\end{array}$ & $\begin{array}{l}.395^{* * *} \\
(.079)\end{array}$ & $\begin{array}{c}.069 \\
(.064)\end{array}$ & $\begin{array}{l}.794^{* * *} \\
(.078)\end{array}$ & $\begin{array}{l}.637^{\text {*** }} \\
(.189)\end{array}$ \\
\hline Unempl. Rate & & $\begin{array}{c}1.139^{* * *} \\
(.403)\end{array}$ & $\begin{array}{l}1.079^{* *} \\
(.404)\end{array}$ & $\begin{array}{l}.885^{* * *} \\
(.409)\end{array}$ & $\begin{array}{c}-1.154^{* * *} \\
(.333)\end{array}$ & $\begin{array}{l}-.079 \\
(.334)\end{array}$ & $\begin{array}{l}-.672^{*} \\
(.350)\end{array}$ \\
\hline Labour Tax Rate & & & & $\begin{array}{l}-.144 \\
(.107)\end{array}$ & $\begin{array}{l}-.088 \\
(.090)\end{array}$ & $\begin{array}{c}.079 \\
(.093)\end{array}$ & $\begin{array}{l}.184^{* *} \\
(.093)\end{array}$ \\
\hline PV Capital Allowances & & & & $\begin{array}{c}.315 \\
(.431)\end{array}$ & $\begin{array}{l}-.401 \\
(.309)\end{array}$ & $\begin{array}{c}.761 \\
(.447)\end{array}$ & $\begin{array}{c}.514 \\
(.450)\end{array}$ \\
\hline Log Sales & & & & $\begin{array}{l}.112^{* * *} \\
(.021)\end{array}$ & $\begin{array}{l}.107^{* * *} \\
(.018)\end{array}$ & $\begin{array}{l}.250^{* * *} \\
(.052)\end{array}$ & $\begin{array}{l}.323^{* * *} \\
(.099)\end{array}$ \\
\hline Log Wage & & & & & $\begin{array}{c}-.737^{* * *} \\
(.022)\end{array}$ & & $\begin{array}{l}-.265 \\
(.228)\end{array}$ \\
\hline Profitability & & & & & $\begin{array}{l}.274^{* * *} \\
(.005)\end{array}$ & & $\begin{array}{l}.153^{* * *} \\
(.041)\end{array}$ \\
\hline $\begin{array}{l}\text { Year D. } \\
\text { Industry-Year D. }\end{array}$ & $\sqrt{ }$ & $\sqrt{ }$ & $\begin{array}{l}\sqrt{ } \\
\sqrt{ }\end{array}$ & $\begin{array}{l}\sqrt{ } \\
\sqrt{ }\end{array}$ & $\begin{array}{l}\sqrt{ } \\
\sqrt{ }\end{array}$ & $\begin{array}{l}\sqrt{ } \\
\sqrt{ }\end{array}$ & $\begin{array}{l}\sqrt{ } \\
\sqrt{ }\end{array}$ \\
\hline $\begin{array}{l}\operatorname{AR}(2) \\
\text { Sargan/Hansen }\end{array}$ & - & - & - & - & - & $\begin{array}{l}0.448 \\
0.605\end{array}$ & $\begin{array}{l}0.277 \\
0.206\end{array}$ \\
\hline \# Observations & 86,623 & 86,623 & 86,297 & 78,960 & 76,076 & 53,041 & 44,424 \\
\hline \# Firms & 22,114 & 22,114 & 21,992 & 19,999 & 19,202 & 15,155 & 13,235 \\
\hline$R^{2}$ Within & 0.0736 & 0.0749 & 0.0791 & 0.0929 & 0.3984 & - & - \\
\hline
\end{tabular}

Heteroskedasticity robust standard errors adjusted for firm clusters in parentheses. ${ }^{*},{ }^{* *},{ }^{* * *}$ indicates significance at the $10 \%, 5 \%, 1 \%$ level. The observational unit is the multinational affiliate per sample year. The dependent variable is the logarithm of the affiliate's labour-to-fixed asset-ratio. In specifications (1) to (5) a fixed effect model is estimated while specifications (6) to (7) estimate a dynamic first difference GMM model as proposed by Arellano and Bond (1991). Sargan/Hansen indicates the p-value of the Sargan-Hansen overidentification test. AR(2) depicts the p-value for the test of second order autocorrelation. Tax Differential stands for the unweighted average difference between the host country's statutory corporate tax rate and the statutory corporate tax rate of other firms within the multinational group. $\log G D P$ and $\log G D P p C$ indicate the logarithm of the host country's gross domestic product and gross domestic product per captita. Corruption is an index for the host country's corruption level, Unemp. Rate stands for the unemployment rate, $P V$ Capital Allowances for the present value of capital allowances for corporate taxation, Labour Tax Rate for the labour tax wedge of a person who earns the median country income, Year D. for a full set of year dummies and Industry-Year D. for a full set of two-digit industry-year dummies. Moreover, Log Sales is the logarithm of the affiliate's sales which proxies for the firm's size, Log Wage is the logarithm of the average affiliate worker's yearly wage rate and Log Pre-tax Profitability is the logarithm of the affiliate's pre-tax profitability as measured by pre-tax profits over fixed assets. 


\begin{tabular}{|c|c|c|c|c|c|c|c|}
\hline \multicolumn{8}{|c|}{$\begin{array}{c}\text { Table 6a: Quality Effect - Impact of Taxes on Payroll Intensity } \\
\text { Dep. Variable: Log Payroll Intensity, Panel 2000-2006 }\end{array}$} \\
\hline Model & \multicolumn{5}{|c|}{ Fixed Effects Model } & \multicolumn{2}{|c|}{ GMM Model } \\
\hline Explanat. Var.: & (1) & (2) & (3) & (4) & (5) & (6) & (7) \\
\hline Lag Payroll Int. & & & & & & $\begin{array}{l}.376^{* * *} \\
(.088)\end{array}$ & $\begin{array}{l}.313^{* * *} \\
(.091)\end{array}$ \\
\hline Corporate Tax Rate & $\begin{array}{l}1.207^{* * *} \\
(.226)\end{array}$ & $\begin{array}{l}1.195^{* * *} \\
(.225)\end{array}$ & $\begin{array}{l}1.091^{* * *} \\
(.225)\end{array}$ & $\begin{array}{l}1.300^{* * *} \\
(.236)\end{array}$ & $\begin{array}{l}1.436^{* * *} \\
(.200)\end{array}$ & $\begin{array}{l}.658^{* * *} \\
(.196)\end{array}$ & $\begin{array}{l}.730^{* * *} \\
(.238)\end{array}$ \\
\hline Log GDP per Capita & & $\begin{array}{l}-.037 \\
(.114)\end{array}$ & $\begin{array}{l}-.120 \\
(.115)\end{array}$ & $\begin{array}{c}-.309^{* * *} \\
(.117)\end{array}$ & $\begin{array}{c}-.367^{* * *} \\
(.109)\end{array}$ & $\begin{array}{c}-.245^{* * *} \\
(.100)\end{array}$ & $\begin{array}{c}-.160^{* * *} \\
(.128)\end{array}$ \\
\hline Log GDP & & $\begin{array}{l}-.075 \\
(.065)\end{array}$ & $\begin{array}{l}-.069 \\
(.066)\end{array}$ & $\begin{array}{l}-.071 \\
(.066)\end{array}$ & $\begin{array}{c}.010 \\
(.070)\end{array}$ & $\begin{array}{l}-.029 \\
(.021)\end{array}$ & $\begin{array}{l}-.024 \\
(.035)\end{array}$ \\
\hline Corruption Index & & $\begin{array}{l}.0042 \\
(.069)\end{array}$ & $\begin{array}{c}.008 \\
(.070)\end{array}$ & $\begin{array}{c}.051 \\
(.072)\end{array}$ & $\begin{array}{c}.017 \\
(.062)\end{array}$ & $\begin{array}{l}.114^{* *} \\
(.059)\end{array}$ & $\begin{array}{c}.057 \\
(.058)\end{array}$ \\
\hline Unempl. Rate & & $\begin{array}{l}-.412 \\
(.362)\end{array}$ & $\begin{array}{l}-.560 \\
(.362)\end{array}$ & $\begin{array}{l}-.710^{*} \\
(.371)\end{array}$ & $\begin{array}{c}-1.648^{* * *} \\
(.316)\end{array}$ & $\begin{array}{l}-.491 \\
(.333)\end{array}$ & $\begin{array}{l}-.543 \\
(.330)\end{array}$ \\
\hline Labour Tax Rate & & & & $\begin{array}{l}-.024 \\
(.103)\end{array}$ & $\begin{array}{l}-.076 \\
(.090)\end{array}$ & $\begin{array}{c}.062 \\
(.098)\end{array}$ & $\begin{array}{c}.087 \\
(.099)\end{array}$ \\
\hline PV Capital Allowances & & & & $\begin{array}{l}-.468 \\
(.351)\end{array}$ & $\begin{array}{c}-1.048^{* * *} \\
(.298)\end{array}$ & $\begin{array}{l}-.110 \\
(.331)\end{array}$ & $\begin{array}{l}-.139 \\
(.348)\end{array}$ \\
\hline Log Sales & & & & $\begin{array}{l}.198^{* * *} \\
(.017)\end{array}$ & $\begin{array}{l}.110^{* * *} \\
(.016)\end{array}$ & $\begin{array}{l}.401^{* * *} \\
(.049)\end{array}$ & $\begin{array}{l}.257^{* *} \\
(.120)\end{array}$ \\
\hline Log Pre-tax Profitability & & & & & $\begin{array}{l}.287^{* * *} \\
(.005)\end{array}$ & & $\begin{array}{c}.068 \\
(.052)\end{array}$ \\
\hline $\begin{array}{l}\text { Year D. } \\
\text { Industry-Year D. }\end{array}$ & $\sqrt{ }$ & $\sqrt{ }$ & $\begin{array}{l}\sqrt{ } \\
\sqrt{ }\end{array}$ & $\begin{array}{l}\sqrt{ } \\
\sqrt{ }\end{array}$ & $\begin{array}{l}\sqrt{ } \\
\sqrt{ }\end{array}$ & $\begin{array}{l}\sqrt{ } \\
\sqrt{ }\end{array}$ & $\begin{array}{l}\sqrt{ } \\
\sqrt{ }\end{array}$ \\
\hline $\begin{array}{l}\operatorname{AR}(2) \\
\text { Sargan/Hansen }\end{array}$ & & & & & & $\begin{array}{l}0.530 \\
0.188\end{array}$ & $\begin{array}{l}0.870 \\
0.581\end{array}$ \\
\hline \# Observations & 95,636 & 95,636 & 95,296 & 88,074 & 88,074 & 58,370 & 50,350 \\
\hline \# Firms & 24,925 & 24,925 & 24,797 & 22,901 & 22,901 & 17,061 & 15,268 \\
\hline$R^{2}$ Within & 0.0072 & 0.0072 & 0.0111 & 0.0305 & 0.2595 & - & - \\
\hline
\end{tabular}

Notes:

Heteroskedasticity robust standard errors adjusted for firm clusters in parentheses. ${ }^{*},{ }^{* *},{ }^{* * *}$ indicates significance at the $10 \%, 5 \%, 1 \%$ level. The observational unit is the multinational affiliate per sample year. The dependent variable is the logarithm of the affiliate's payroll-to-fixed asset-ratio. In specifications (1) to (5) a fixed effect model is estimated while specifications (6) to (7) estimate a dynamic first difference GMM model as proposed by Arellano and Bond (1991). Sargan/Hansen indicates the p-value of the Sargan-Hansen overidentification test. AR(2) depicts the p-value for the test of second order autocorrelation. Stat. Corporate Tax stands for the host country's statutory corporate tax rate and EMTR for its effective marginal tax rate. $\log G D P$ and $\log G D P p C$ indicate the logarithm of the host country's gross domestic product and gross domestic product per captita. Corruption is an index for the host country's corruption level, Unemp. Rate stands for the unemployment rate, PV Capital Allowances for the present value of capital allowances for corporate taxation, Labour Tax Rate for the labour tax wedge of a person who earns the median country income, Year $D$. for a full set of year dummies and Industry-Year D. for a full set of two-digit industry-year dummies. Moreover, Log Sales is the logarithm of the affiliate's sales which proxies for the firm's size and Log Pre-tax Profitability is the logarithm of the affiliate's pre-tax profitability as measured by pre-tax profits over fixed assets. 


\begin{tabular}{|c|c|c|c|c|c|c|c|}
\hline \multicolumn{8}{|c|}{$\begin{array}{c}\text { Table 6b: Quality Effect - Impact of Taxes on Payroll Intensity } \\
\text { Dep. Variable: Payroll Intensity, Panel 2000-2006 }\end{array}$} \\
\hline \multirow{2}{*}{$\begin{array}{l}\text { Model } \\
\text { Explanat. Var.: }\end{array}$} & \multicolumn{5}{|c|}{ Fixed Effects Model } & \multicolumn{2}{|c|}{ GMM Model } \\
\hline & (1) & (2) & (3) & (4) & (5) & (6) & (7) \\
\hline Lag Payroll Int. & & & & & & $\begin{array}{l}.284^{* * *} \\
(.094)\end{array}$ & $\begin{array}{l}.353^{* * *} \\
(.105)\end{array}$ \\
\hline Tax Differential & $\begin{array}{c}.026 \\
(.138)\end{array}$ & $\begin{array}{c}.026 \\
(.138)\end{array}$ & $\begin{array}{c}.022 \\
(.139)\end{array}$ & $\begin{array}{c}.136 \\
(.144)\end{array}$ & $\begin{array}{l}.352^{* * *} \\
(.125)\end{array}$ & $\begin{array}{c}.199 \\
(.124)\end{array}$ & $\begin{array}{l}.306^{* *} \\
(.132)\end{array}$ \\
\hline Log GDP per Capita & & $\begin{array}{c}.054 \\
(.113)\end{array}$ & $\begin{array}{l}-.040 \\
(.114)\end{array}$ & $\begin{array}{r}-.226^{* *} \\
(.115)\end{array}$ & $\begin{array}{c}-.344^{* * *} \\
(.109)\end{array}$ & $\begin{array}{l}-.159 \\
(.135)\end{array}$ & $\begin{array}{c}.024 \\
(.128)\end{array}$ \\
\hline Log GDP & & $\begin{array}{l}-.048 \\
(.054)\end{array}$ & $\begin{array}{l}-.045 \\
(.056)\end{array}$ & $\begin{array}{l}-.044 \\
(.054)\end{array}$ & $\begin{array}{c}.034 \\
(.063)\end{array}$ & $\begin{array}{l}-.012 \\
(.023)\end{array}$ & $\begin{array}{l}-.006 \\
(.012)\end{array}$ \\
\hline Corruption Index & & $\begin{array}{l}-.059 \\
(.073)\end{array}$ & $\begin{array}{l}-.042 \\
(.074)\end{array}$ & $\begin{array}{l}.018 \\
(.075)\end{array}$ & $\begin{array}{l}-.035 \\
(.065)\end{array}$ & $\begin{array}{c}.065 \\
(.059)\end{array}$ & $\begin{array}{c}.014 \\
(.067)\end{array}$ \\
\hline Unempl. Rate & & $\begin{array}{l}-.267 \\
(.384)\end{array}$ & $\begin{array}{l}-.395 \\
(.384)\end{array}$ & $\begin{array}{l}-.488 \\
(.392)\end{array}$ & $\begin{array}{c}-1.454^{* * *} \\
(.335)\end{array}$ & $\begin{array}{l}-.827^{* *} \\
(.349)\end{array}$ & $\begin{array}{l}-.260 \\
(.362)\end{array}$ \\
\hline Labour Tax Rate & & & & $\begin{array}{l}-.102 \\
(.106)\end{array}$ & $\begin{array}{l}-.100 \\
(.092)\end{array}$ & $\begin{array}{c}.114 \\
(.102)\end{array}$ & $\begin{array}{c}.054 \\
(.166)\end{array}$ \\
\hline PV Capital Allowances & & & & $\begin{array}{l}.161 \\
(.358)\end{array}$ & $\begin{array}{l}-.463 \\
(.304)\end{array}$ & $\begin{array}{l}-.068 \\
(.353)\end{array}$ & $\begin{array}{l}-.144 \\
(.308)\end{array}$ \\
\hline Log Sales & & & & $\begin{array}{l}.221^{* * *} \\
(.018)\end{array}$ & $\begin{array}{l}.132^{* * *} \\
(.017)\end{array}$ & $\begin{array}{l}.273^{* *} \\
(.120)\end{array}$ & $\begin{array}{l}.169^{*} \\
(.101)\end{array}$ \\
\hline Profitability & & & & & $\begin{array}{l}.275^{* * *} \\
(.005)\end{array}$ & $\begin{array}{l}.118^{* *} \\
(.054)\end{array}$ & $\begin{array}{l}.138^{*} \\
(.072)\end{array}$ \\
\hline $\begin{array}{l}\text { Year D. } \\
\text { Industry-Year D. }\end{array}$ & $\sqrt{ }$ & $\sqrt{ }$ & $\begin{array}{l}\sqrt{ } \\
\sqrt{ }\end{array}$ & $\begin{array}{l}\sqrt{ } \\
\sqrt{ }\end{array}$ & $\begin{array}{l}\sqrt{ } \\
\sqrt{ }\end{array}$ & $\begin{array}{l}\sqrt{ } \\
\sqrt{ }\end{array}$ & $\begin{array}{l}\sqrt{ } \\
\sqrt{ }\end{array}$ \\
\hline $\operatorname{AR}(2)$ & - & - & - & - & - & 0.976 & 0.909 \\
\hline Sargan/Hansen & - & - & - & - & - & 0.434 & 0.217 \\
\hline \# Observations & 82,143 & 82,143 & 81,831 & 75,525 & 75,525 & 43,992 & 23,967 \\
\hline \# Firms & 20,843 & 20,843 & 20,730 & 19,081 & 19,081 & 13,146 & 7,067 \\
\hline$R^{2}$ Within & 0.0038 & 0.0038 & 0.0080 & 0.0330 & 0.2480 & - & - \\
\hline
\end{tabular}

Notes:

Heteroskedasticity robust standard errors adjusted for firm clusters in parentheses. ${ }^{*},{ }^{* *},{ }^{* * *}$ indicates significance at the $10 \%, 5 \%, 1 \%$ level. The observational unit is the multinational affiliate per sample year. The dependent variable is the logarithm of the affiliate's labour-to-fixed asset-ratio. In specifications (1) to (5) a fixed effect model is estimated while specifications (6) to (7) estimate a dynamic first difference GMM model as proposed by Arellano and Bond (1991). Sargan/Hansen indicates the p-value of the Sargan-Hansen overidentification test. AR(2) depicts the p-value for the test of second order autocorrelation. Tax Differential stands for the unweighted average difference between the host country's statutory corporate tax rate and the statutory corporate tax rate of other firms within the multinational group. $\log G D P$ and $\log G D P p C$ indicate the logarithm of the host country's gross domestic product and gross domestic product per captita. Corruption is an index for the host country's corruption level, Unemp. Rate stands for the unemployment rate, $P V$ Capital Allowances for the present value of capital allowances for corporate taxation, Labour Tax Rate for the labour tax wedge of a person who earns the median country income, Year D. for a full set of year dummies and Industry-Year D. for a full set of two-digit industry-year dummies. Moreover, Log Sales is the logarithm of the affiliate's sales which proxies for the firm's size and Log Pre-tax Profitability is the logarithm of the affiliate's pre-tax profitability as measured by pre-tax profits over fixed assets. 


\begin{tabular}{|c|c|c|c|c|c|c|}
\hline \multicolumn{7}{|c|}{$\begin{array}{c}\text { Table 7: Wage Effect - Impact of Taxes on the Average Wage } \\
\text { Dep. Variable: Average Yearly Wage, Panel 2000-2006 }\end{array}$} \\
\hline Explanat. Var.: & (1) & (2) & (3) & (4) & (5) & (6) \\
\hline Lag Avg. Yearly Wage & & & & & & $\begin{array}{c}.139 \\
(.095)\end{array}$ \\
\hline Tax Rate & $\begin{array}{c}-.257^{* *} \\
(.122)\end{array}$ & $\begin{array}{c}-.549^{* * *} \\
(.115)\end{array}$ & $\begin{array}{c}-.548^{* * *} \\
(.116)\end{array}$ & $\begin{array}{c}-.489^{* * *} \\
(.117)\end{array}$ & $\begin{array}{c}-.443^{* * *} \\
(.103)\end{array}$ & $\begin{array}{r}-.661^{* * *} \\
(.215)\end{array}$ \\
\hline Log GDP per Capita & & $\begin{array}{l}.362^{* * *} \\
(.052)\end{array}$ & $\begin{array}{l}.379^{* * *} \\
(.052)\end{array}$ & $\begin{array}{l}.275^{* * *} \\
(.052)\end{array}$ & $\begin{array}{l}.234^{* * *} \\
(.052)\end{array}$ & $\begin{array}{l}.666^{* * *} \\
(.097)\end{array}$ \\
\hline Log GDP & & $\begin{array}{l}-.016 \\
(.018)\end{array}$ & $\begin{array}{l}-.019 \\
(.018)\end{array}$ & $\begin{array}{l}-.019 \\
(.018)\end{array}$ & $\begin{array}{l}-.021 \\
(.022)\end{array}$ & $\begin{array}{l}-.037^{* *} \\
(.017)\end{array}$ \\
\hline Corruption Index & & $\begin{array}{l}-.375 \\
(.035)\end{array}$ & $\begin{array}{l}-.372 \\
(.035)\end{array}$ & $\begin{array}{c}-.381^{* * *} \\
(0.036)\end{array}$ & $\begin{array}{l}-.324 \\
(.034)\end{array}$ & $\begin{array}{c}-.653^{* * *} \\
(.059)\end{array}$ \\
\hline Unempl. Rate & & $\begin{array}{c}-1.229^{* * *} \\
(.147)\end{array}$ & $\begin{array}{c}-1.246^{* * *} \\
(.149)\end{array}$ & $\begin{array}{c}-1.131^{* * *} \\
(.152)\end{array}$ & $\begin{array}{c}-1.271^{* * *} \\
(.142)\end{array}$ & $\begin{array}{c}.011 \\
(.193)\end{array}$ \\
\hline Labour Tax Rate & & & & $\begin{array}{c}-.102^{* *} \\
(.046)\end{array}$ & $\begin{array}{l}-.098^{* *} \\
(.044)\end{array}$ & $\begin{array}{l}.114 \\
(.102)\end{array}$ \\
\hline Log Sales & & & & $\begin{array}{l}.111^{\text {*** }} \\
(.009)\end{array}$ & $\begin{array}{l}.106^{* * *} \\
(.009)\end{array}$ & $\begin{array}{l}.018 \\
(.137)\end{array}$ \\
\hline Log Labour Productivity & & & & & $\begin{array}{l}.067^{\text {*** }} \\
(.003)\end{array}$ & $\begin{array}{c}.072 \\
(.048)\end{array}$ \\
\hline $\begin{array}{l}\text { Year D. } \\
\text { Industry-Year D. }\end{array}$ & $\sqrt{ }$ & $\sqrt{ }$ & $\begin{array}{l}\sqrt{ } \\
\sqrt{ }\end{array}$ & $\begin{array}{l}\sqrt{ } \\
\sqrt{ }\end{array}$ & $\begin{array}{l}\sqrt{ } \\
\sqrt{ }\end{array}$ & $\begin{array}{l}\sqrt{ } \\
\sqrt{ }\end{array}$ \\
\hline $\begin{array}{l}\operatorname{AR}(2) \\
\text { Sargan/Hansen }\end{array}$ & - & $\begin{array}{l}- \\
-\end{array}$ & $\begin{array}{l}- \\
-\end{array}$ & $\begin{array}{l}- \\
-\end{array}$ & - & $\begin{array}{l}0.748 \\
0.444\end{array}$ \\
\hline \# Observations & 95,636 & 95,636 & 95,296 & 88,074 & 82,133 & 51,709 \\
\hline \# Firms & 24,925 & 24,925 & 24,797 & 22,901 & 21,822 & 15,341 \\
\hline$R^{2}$ Within & 0.3966 & 0.4020 & 0.4031 & 0.4314 & 0.4784 & - \\
\hline
\end{tabular}

Notes:

Heteroskedasticity robust standard errors adjusted for firm clusters in parentheses. ${ }^{*},{ }^{* *},{ }^{* * *}$ indicates significance at the $10 \%, 5 \%, 1 \%$ level. The observational unit is the multinational affiliate per sample year. The dependent variable is the logarithm of the yearly wage cost for the average affiliate worker. In specifications (1) to (5) a fixed effect model is estimated while specification (6) estimates a dynamic first difference GMM model as proposed by Arellano and Bond (1991). Sargan/Hansen indicates the p-value of the Sargan-Hansen overidentification test. AR(2) depicts the p-value for the test of second order autocorrelation. Stat. Corporate Tax stands for the host country's statutory corporate tax rate and EMTR for its effective marginal tax rate. $\log G D P$ and $\log G D P p C$ indicate the logarithm of the host country's gross domestic product and gross domestic product per captita. Corruption is an index for the host country's corruption level, Unemp. Rate stands for the unemployment rate, Labour Tax Rate for the labour tax wedge of a person who earns the median country income, Year D. for a full set of year dummies and Industry-Year D. for a full set of two-digit industry-year dummies. Moreover, Log Sales is the logarithm of the affiliate's sales which proxies for the firm's size and Log Labour Productivity is the logarithm of the affiliate's labour productivity as measured by earnings before interest and tax over the number of employees. 


\section{OXford University Centre for Business TAXation WORKING PAPER SERIES}

WP10/13 Becker, Johannes, Fuest, Clemens and Nadine Riedel, Corporate tax effects on the quality and quantity of FDI

WP10/12 Fuest, Clemens and Nadine Riedel, Tax Evasion and Tax Avoidance in Developing Countries: The Role of International Profit Shifting

WP10/11 Wildasin, David E., State Corporation Income Taxation: An Economic Perspective on Nexus

WP10/10 Becker, Johannes and Marco Runkel, Corporate tax regime and international allocation of ownership

WP10/09 Simpson, Helen, How do firms' outward FDI strategies relate to their activity at home? Empirical evidence for the UK

WP10/08 Voget, Johannes, Headquarter Relocations and International Taxation

WP10/07 Devereux, Michael P. and Simon Loretz, Evaluating Neutrality Properties of Corporate Tax Reforms

WP10/06 Davies, Ronald B. and Lourenço S. Paz, Tariffs Versus VAT in the Presence of Heterogeneous Firms and an Informal Sector

WP10/05 Finke, Katharina, Heckemeyer, Jost H., Reister Timo and Christoph Spengel, Impact of Tax Rate Cut Cum Base Broadening Reforms on Heterogeneous Firms - Learning from the German Tax Reform 2008

WP10/04 Koh, Hyun-Ju and Nadine Riedel, Do Governments Tax Agglomeration Rents?

WP10/03 Dischinger, Matthias and Nadine Riedel, The Role of Headquarters in Multinational Profit Shifting Strategies

WP10/02 Vrijburg, Hendrik and Ruud A. de Mooij, Enhanced Cooperation in an asymmetric model of Tax Competition

WP10/01 Bettendorf, Leon, van der Horst, Albert, de Mooij, Ruud A. and Hendrik Vrijburg, Corporate tax consolidation and enhanced cooperation in the European Union

WP09/32 Bettendorf, Leon, Devereux, Michael P., van der Horst, Albert, Loretz, Simon and Ruud A. de Mooij, Corporate tax harmonization in the EU

WP09/31 Karkinsky, Tom and Nadine Riedel, Corporate Taxation and the Choice of Patent Location within Multinational Firms 
WP09/30 Becker, Johannes and Clemens Fuest, Transfer Pricing Policy and the Intensity of Tax Rate Competition

WP09/29 de la Feria, Rita, VAT and the EC Internal Market: The Shortcomings of Harmonisation

WP09/28 Damjanovic, Tatiana and David Ulph, Tax Progressivity, Income Distribution and Tax Non-Compliance

WP09/27 Grubert, Harry, MNC Dividends, Tax Holidays and the Burden of the Repatriation Tax: Recent Evidence

WP09/26 Grubert, Harry, Foreign Taxes, Domestic Income, and the Jump in the Share of Multinational Company Income Abroad

WP09/25 Maffini, Giorgia, Tax Haven Activities and the Tax Liabilities of Multinational Groups

WP09/24 Bach,Laurent and Nicolas Serrano-Velarde, The Power of Dynastic Commitment

WP09/23 Dischinger, Matthias and Nadine Riedel, There's No Place Like Home: The Profitability Gap between Headquarters and their Foreign Subsidiaries

WP09/22 Ulph, David, Avoidance Policies - A New Conceptual Framework

WP09/21 Ulph, Alistair and David Ulph, Optimal Climate Change Policies When Governments Cannot Commit

WP09/20 Maffini, Giorgia and Socrates Mokkas, Profit-Shifting and Measured Productivity of Multinational Firms

WP09/19 Devereux, Michael P., Taxing Risky Investment

WP09/18 Buettner, Thiess and Georg Wamser, Internal Debt and Multinationals' Profit Shifting - Empirical Evidence from Firm-Level Panel Data

WP09/17 Arulampalam, Wiji, Devereux, Michael P. and Giorgia Maffini, The Direct Incidence of Corporate Income Tax on Wages

WP09/16 Keuschnigg, Christian and Evelyn Ribi, Profit Taxation and Finance Constraints

WP09/15 Shaviro, Daniel N., Planning and Policy Issues raised by the Structure of the U.S. International Tax Rules

WP09/14 Karkinsky, Tom and Nadine Riedel, Corporate Taxation and the Choice of Patent Location within Multinational Firms

WP09/13 Koh, Hyun-Ju and Nadine Riedel, Assessing the Localization Pattern of German Manufacturing \& Service Industries - A Distance Based Approach

WP09/12 Loretz, Simon and Padraig J. Moore, Corporate Tax Competition between Firms 